Supporting information for

\title{
Operando Generated Ordered Heterogeneous Catalyst for the Selective Conversion of $\mathrm{CO}_{2}$ to Methanol
}

\author{
Arjun Cherevotan, ${ }^{1,2}$ Jithu Raj, ${ }^{1,2 \#}$ Lakshay Dheer, ${ }^{2,3,4 \#}$ Soumyabrata
}

Roy, ${ }^{1,2 \$}$ Shreya Sarkar, ${ }^{1,2}$ Risov Das, ${ }^{1,2}$ Chathakudath P. Vinod, ${ }^{5}$ Shaojun

$\mathrm{Xu}^{6,7}$ Peter Wells, ${ }^{6,8,9}$ Umesh V. Waghmare ${ }^{2,3}$ and Sebastian C. Peter ${ }^{1,2 *}$

${ }^{1}$ New Chemistry Unit, Jawaharlal Nehru Centre for Advanced Scientific Research, Jakkur, Bangalore-560064

${ }^{2}$ School of Advanced Materials, Jawaharlal Nehru Centre for Advanced Scientific Research, Jakkur, Bangalore-560064

${ }^{3}$ Theoretical Sciences Unit, Jawaharlal Nehru Centre for Advanced Scientific Research, Jakkur, Bangalore-560064

${ }^{4}$ Chemistry and Physics of Materials Unit, Jawaharlal Nehru Centre for Advanced Scientific Research, Jakkur, Bangalore-560064

${ }^{5}$ Catalysis and Inorganic Chemistry Division, National Chemical laboratory, Dr. Homi Bhabha Road, Pune, 410008

${ }^{6} U K$ Catalysis Hub, Research Complex at Harwell, Didcot, OX11 OFA, UK

${ }^{7}$ Cardiff Catalysis Institute, School of Chemistry, Cardiff University, Cardiff, CF 10 3AT, UK ${ }^{8}$ School of Chemistry, University of Southampton, Southampton, UK

${ }^{9}$ Diamond Light Source, Didcot, UK

*Corresponding author. Phone: 080-22082998, Fax: 080-22082627

sebastiancp@jncasr.ac.in (S. C. Peter)

\#Equally Contributed

\$Present Address: Department of Materials Science and Nanoengineering, Rice University, Houston, TX, United States 


\section{S1. Experimental Sections:}

\subsection{Materials:}

Tetraethyl orthosilicate (TEOS) (>99\% GC, Sigma Aldrich), pluronic P123 ( $\mathrm{M}_{\mathrm{n}} \sim 5800$, Sigma Aldrich), $\mathrm{HNO}_{3}$ (69\% analytical grade, Merck Chemicals), $\mathrm{H}_{2} \mathrm{SO}_{4}$ (98\% analytical grade, Merck Chemicals), nickel nitrate hexahydrate (98\%, SDFCL) and indium nitrate hydrate (99.99\%, Sigma Aldrich).

\subsection{Synthesis:}

SBA-15: The support material Santa Barbara Amorphous (SBA-15) ${ }^{1}$ was synthesized by modifying an already reported method. ${ }^{2}$ Four grams of Pluronic P123 was dissolved in 105 $\mathrm{mL}$ of deionized water and $10.8 \mathrm{~mL}$ of $98 \% \mathrm{H}_{2} \mathrm{SO}_{4}$ to act as a soft template. Then $9.063 \mathrm{~mL}$ of TEOS was added to the solution with high rate of stirring for 3.5 hours at $313 \mathrm{~K}$, followed by hydrothermal treatment at $373 \mathrm{~K}$ for 30 hours. The obtained white powder was filtered, washed with deionized water, and dried at $373 \mathrm{~K}$ overnight. Lastly it was calcined for 6 hours at $823 \mathrm{~K}$.

$N i-I n / S B A-15:$ A typical method of incipient wetness impregnation was followed with slight modification to distribute Ni-In system on SBA-15. ${ }^{3}{ }^{4} \mathrm{Ni}(\mathrm{II})$ and $\mathrm{In}(\mathrm{III})$ nitrates were dissolved in $4 \mathrm{M} \mathrm{HNO}_{3}$ solution. The nitrate salts were weighed so as to get $23 \%$ of metal loading with different ratio of Ni:In - 3:1 (Ni-In/SBA-15-a), 2:1 (Ni-In/SBA-15-b), 1:1 (NiIn/SBA-15-c) and 7:3 (Ni-In/SBA-15-d). SBA-15 was soaked in the solution for an hour, which propels the solution impregnation into the channels by capillary action. The excess solution was dried at $333 \mathrm{~K}$ in fume hood and further in vacuum oven at $393 \mathrm{~K}$ overnight. The precursor was reduced at $1083 \mathrm{~K}$ under $\mathrm{H}_{2}$ flow (Figure 1). The controlled catalyst (without In) Ni/SBA-15 was synthesized by following same steps. The NiO- $\operatorname{In}_{2} \mathrm{O}_{3} / \mathrm{SBA}-15$ was synthesized by oxidizing Ni-In/SBA-15-d at $773 \mathrm{~K}$ for 5 hours under air.

Interestingly, identical features were observed in the XRD patterns of all the aforementioned combinations of $\mathrm{Ni}-\mathrm{In}\left(\mathrm{NiIn}, \mathrm{Ni}_{2} \mathrm{In}, \mathrm{Ni}_{3} \mathrm{In}\right.$ and $\mathrm{Ni}_{7} \mathrm{In}_{3}$ ) phases on SBA-15 
regardless of the ratio of metal precursor solution (Figure S1), which confirm the formation of triclinic $\mathrm{Ni}_{7} \mathrm{In}_{3}$ IMC phase having space group $P \overline{1}$. Among the four phases, $\mathrm{Ni}_{7} \mathrm{In}_{3} / \mathrm{SBA}-15$ was found to form in the pure targeted phase up to the XRD detection limits (Figure S1 and S2b). On the other hand, peaks at $41.6^{\circ}$ and $48.5^{\circ}$ corresponding

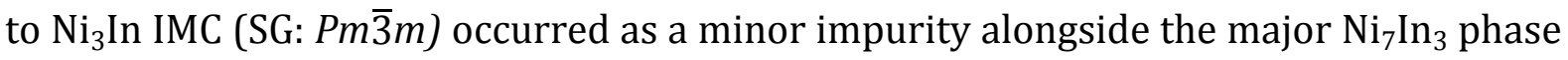
obtained in $\mathrm{Ni}_{3} \mathrm{In} / \mathrm{SBA}-15$ (Figure S2) synthesis. The other targeted phases $\mathrm{Ni}_{3} \mathrm{In} / \mathrm{SBA}$ 15 and $\mathrm{Ni}_{2} \mathrm{In} / \mathrm{SBA}-15$ lead to the formation of $\mathrm{Ni}(F m \overline{3} m)$ as a minor phase along with $\mathrm{Ni}_{7} \mathrm{In}_{3}$ as the major phase.

\subsection{Material Charactarization:}

The phase formation on SBA-15 was confirmed by X-ray diffraction (XRD) collected on PANalytical X-ray diffractometer with $\mathrm{Cu} \mathrm{K \alpha}$ radiation at $45 \mathrm{kV}$ and $40 \mathrm{~mA}$. The features of the PXRD patterns were compared with simulated pattern from Pearson Database. The adsorption isotherms were studied by using $\mathrm{N}_{2}$ at $77 \mathrm{~K}$ on BelCat instrument. Prior to the measurements the powders were treated for degassing at $423 \mathrm{~K}$ for 6 hours. The specific surface area was confirmed by Brunaur-Emmett-Teller (BET) method and pore size distribution by classical BJH (Barrett, Joyner and Halenda) method. TEM images and selected area electron diffraction patterns were collected using a JEOL JEM-2010 TEM instrument and color mapping was done in TECHNAI. The samples for these measurements were prepared by sonicating the nanocrystalline powders in ethanol and drop-casting a small volume onto a carbon-coated copper grid.

The TEM and SEM micrographs of SBA-15 visualize the separated hexagonal channels of the mesoporous support (Figure S2c and Figure S3a). The TEM images for both $\mathrm{Ni} / \mathrm{SBA}-15$ and $\mathrm{Ni}_{7} \mathrm{In}_{3} / \mathrm{SBA}-15$ were indistinguishable due to extensive distribution of metal/IM nanoparticles (NPs) over the channels of SBA-15 (Figure S2d and Figure S4). STEM color mapping on the NPs of $\mathrm{Ni}_{7} \mathrm{In}_{3} / \mathrm{SBA}-15$ shows the uniform elemental 
distribution of $\mathrm{Ni}$ and In all over the spherical nanoparticles confirming the formation of the IMC (Figure S3c), which is well complemented by the SEM images (Figure S3b). The average particle size in the case of $\mathrm{Ni}_{7} \mathrm{In}_{3}$ was found to be $7.7 \mathrm{~nm}$ (Figure S2e).

The $\mathrm{N}_{2}$ adsorption-desorption experiment exhibits type IV isotherm (Brunauer definition) with hysteresis loop (Figure S2f), typical of hexagonal and cylindrical mesoporous materials. ${ }^{5}$ There is a fast increase in adsorption volume between $0.6-0.8$ $\mathrm{p} / \mathrm{p}_{0}$ which is indicative of capillary condensation attributed to the pre-formation of $\mathrm{N}_{2}$ on the pore walls due to multilayer adsorption. ${ }^{6} \mathrm{Ni} / \mathrm{SBA}-15$ and $\mathrm{Ni}_{7} \mathrm{In}_{3} / \mathrm{SBA}-15$ samples, exhibited a left-shift of the sharp rise in the adsorption isotherms and drastically diminished surface areas [from $675 \mathrm{~m}^{2} / \mathrm{g}(\mathrm{SBA}-15)$ to $290 \mathrm{~m}^{2} / \mathrm{g}(\mathrm{Ni} / \mathrm{SBA}-15)$ and 265 $\left.\mathrm{m}^{2} / \mathrm{g}\left(\mathrm{Ni}_{7} \mathrm{In}_{3} / \mathrm{SBA}-15\right)\right]$. This lowering of surface area concludes that impregnated $\mathrm{Ni}$ and $\mathrm{Ni}_{7} \mathrm{In}_{3}$ clusters decreases the $\mathrm{N}_{2}$ probing surface inside the mesopores. ${ }^{7}$ Additionally, the decrease in pore size upon the impregnation further confirms the formation $\mathrm{Ni}$ metal and $\mathrm{Ni}_{7} \mathrm{In}_{3} \mathrm{IMC}$ as nanoparticles within the channels of mesoporous

\section{SBA-15 (Figure S2g).}

\subsection{Catalyst Extrution:}

Wire type extrudates were used for the tubular reactor. A paste was made from catalyst powder by grinding $5 \mathrm{~g}$ of it with $1.5 \mathrm{~g}$ of pseudoboehmite $(\mathrm{AlO}(\mathrm{OH}))$ and $10 \mathrm{~mL}$ of $0.5 \mathrm{M}$ $\mathrm{HNO}_{3}$. This was then passed through a manually operated wire profiled die to get a wire of $0.5 \mathrm{~mm}$ diameter and $1 \mathrm{~mm}$ length. The extrudates were dried in atmospheric conditions and then calcined overnight at $373 \mathrm{~K}$ to make it strong. The extrudates were crushed and characterized by XRD.

\subsection{Catalyst Screening Test:}

The efficiency of the catalysts towards $\mathrm{CO}_{2}$ reduction was screened by a fixed bed vapor phase down flow reactor having a bed volume of $9.2 \mathrm{~cm}^{3}$. Two flow rates were used, that is, 
$40 \mathrm{NLPH}\left(1 \mathrm{CO}_{2}: 3 \mathrm{H}_{2}\right)$ and $50 \mathrm{NLPH}\left(1 \mathrm{CO}_{2}: 4 \mathrm{H}_{2}\right)$. The reactions were performed at $523 \mathrm{~K}$ and $573 \mathrm{~K}$, also at different pressures, that is, ambient to 50 bar. The catalyst after loading was activated by passing 5:10 mixture of $\mathrm{H}_{2}$ and $\mathrm{N}_{2}$ at $673 \mathrm{~K}$. The gases were analyzed in real time by Agilent GC 7890B, with TCD and FID as the detector. The liquid products were condensed by chiller and analysis by FID after 15 hours of reaction. $\mathrm{N}_{2}$ and isopropyl alcohol (IPA) were used as the internal standards for gas and liquid analysis, respectively.

\subsection{X-ray Photoelectron Spectroscopy (XPS):}

XPS measurements were carried out using Thermo K-alpha+ spectrometer using micro focused and monochromated $\mathrm{Al} \mathrm{K \alpha}$ radiation with energy $1486.6 \mathrm{eV}$. The pass energy for spectral acquisition was kept at $50 \mathrm{eV}$ for individual core-levels. The electron flood gun was utilized for providing charge compensation during data acquisition. Further, the individual core-level spectra were checked for charging using $\mathrm{C} 1 \mathrm{~s}$ at $284.6 \mathrm{eV}$ as standard and corrected if needed. The peak fitting of the individual core-levels was done using CASAXPS software with a Shirley type background.

\subsection{XAFS:}

Ni XAFS measurements of Ni-edge of Ni/SBA-15, Ni $\mathrm{In}_{3} / \mathrm{SBA}-15$ and $\mathrm{Ni}_{3} \mathrm{In} / \mathrm{SBA}-15$ were carried out in fluorescence mode at PETRA III, P65 beamline of DESY, Germany. Pellets for the measurements were made by homogenously mixing the sample with an inert cellulose matrix to have an X-ray absorption edge jump close to one. Standard data analysis procedure was used to extract the extended X-ray absorption fine structure (EXAFS) signal from the measured absorption spectra. Background subtraction, normalization, and alignment of the XAFS data were performed by ATHENA software.

\subsection{Operando DRIFTS:}

The operando DRIFTS experimental were carried out using an Agilent Carey 680 FTIR Spectrometer equipped with a Harrick DRIFTS cell. The spectra were recorded at $4 \mathrm{~cm}^{-1}$ 
resolution and each spectrum was averaged 64 times. Each sample was pre-treated at $473 \mathrm{~K}$ using $99.999 \%$ argon (Ar, BOC gas Ltd.) at a gas flow rate of $50 \mathrm{ml} \mathrm{min}^{-1}$ for $1 \mathrm{~h}$ in order to remove adsorbed water and other gas molecules. Then the temperature of the sample was increased to $723 \mathrm{~K}$ and gas switched to $20 \% \mathrm{H}_{2} / \mathrm{Ar}$ at $50 \mathrm{ml} \mathrm{min}^{-1}$ for $2 \mathrm{~h}$ reduction. After that, the temperature of the sample was annealed to $303 \mathrm{~K}$ under Ar flow. The spectrum of the annealed sample at $303 \mathrm{~K}$ was used as the background reference for the following reaction. To probe the reaction, $25 \% \mathrm{CO}_{2} / 75 \% \mathrm{H}_{2}$ gas mixture at 1 bar and a total flow rate of $50 \mathrm{ml}$ $\min ^{-1}$ was first introduce to the DRIFTS cell, and then temperature was ramped from 303 to $573 \mathrm{~K}$ (ca. $15 \mathrm{k} \mathrm{min}^{-1}$ ) to determine the relationship between temperature and the reaction intermedia. Then the reaction was maintained at $573 \mathrm{~K}$ for $1 \mathrm{~h}$ to determine the surface intermedia revolution.

\subsection{Computational Details:}

Our first-principles calculations are based on density functional theory (DFT) as implemented in the Quantum ESPRESSO code employing plane-wave basis and ultra-soft pseudopotentials $^{9}$ to represent the interaction between ionic cores and valence electrons. We adopt the exchange-correlation energy functional of Perdew-Burke-Ernzerhof $(\mathrm{PBE})^{10}$ obtained within a generalized gradient approximation (GGA). We smear the discontinuity in occupation numbers of electronic states with Fermi-Dirac distribution having a smearing width $\left(\mathrm{k}_{\mathrm{B}} \mathrm{T}\right)$ of $0.04 \mathrm{eV}$. An energy cutoff of $50 \mathrm{Ry}$ is used to truncate the plane-wave basis used in representation of Kohn-Sham wave functions, and of 400 Ry to represent the charge density. Optimized structures were determined through minimization of energy until the Hellmann-Feynman force on each atom is smaller than $0.03 \mathrm{eV} / \AA$ in magnitude. We use a

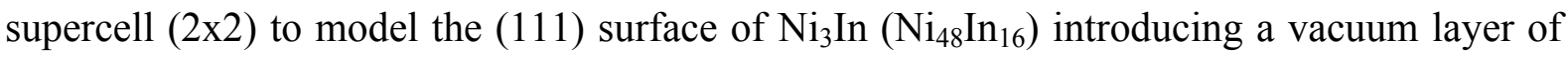
$15 \AA$ thickness parallel to the slab separating its adjacent periodic images. To this end, we modelled $2 \times 2$ in-plane supercell of its (111) surface $\left(\mathrm{Ni}_{48} \mathrm{In}_{16}\right)$. Each supercell contains a slab 
of 4 atomic planes of which, the bottom 2 atomic planes were kept fixed and the top 2 were allowed to relax. We sampled Brillouin-zone integrations on uniform grid of 6x6x1 k-points in the Brillouin zone of (111) surface of $\mathrm{Ni}_{3} \mathrm{In}$. The projected density of states of each structure was obtained from calculations on a denser, $15 \times 15 \times 1$, k-point mesh. Calculated lattice constants of bulk $\mathrm{Ni}_{3} \operatorname{In}\left(\mathrm{a}_{\mathrm{Ni}_{3} I n}=3.74 \AA\right)$ are within the typical GGA errors with respect to their observed values $\left(\mathrm{a}_{N i_{3} I n}=3.73 \AA\right)$. Relative energies of the intermediate steps were plotted taking pristine $\mathrm{Ni}_{3} \mathrm{In}$ (111) surface $+\mathrm{CO}_{2}+3 \mathrm{H}_{2}$ as the reference. We simulated adsorption of various intermediates occurring during the $\mathrm{CO}_{2}$ reduction reaction $\left(\mathrm{CO}_{2} \mathrm{RR}\right)$ and calculated their adsorption energies (see methods for details)

$$
\Delta E_{a d s}=E_{a d s o r b a t e}+N i_{3} I n-\left(E_{N i_{3} I n}+E_{a d s o r b a t e}\right)
$$

where, $E_{\text {adsorbate }+N i_{3} I n}, E_{N i_{3} I n}$ and $E_{\text {adsorbate }}$ are the energies of adsorbate locally stabilized on $\mathrm{Ni}_{3} \mathrm{In}$ (111) surface, bare $\mathrm{Ni}_{3} \operatorname{In}$ (111) surface and the adsorbate molecule, respectively. The transition states (TSs) were obtained using the nudged elastic band (NEB) ${ }^{11}$ method. Five images were used in all the NEB calculations in this paper. All transition states were fully relaxed until the Hellmann-Feynman forces acting on the atoms were within 0.05 $\mathrm{eV} \AA$.

\section{Data Calculations}

\subsection{Weight Hour Space Velocity (WHSV):}

WHSV is defined as the mass of reactant per unit time passed per mass of catalyst charged in a reactor. Here we used two flow rates $40 \mathrm{NLPH}\left(1 \mathrm{CO}_{2}: 3 \mathrm{H}_{2}\right)$ and $50 \mathrm{NLPH}\left(1 \mathrm{CO}_{2}: 4 \mathrm{H}_{2}\right)$.

$\underline{40 \mathrm{NLPH}}$ :

$\mathrm{CO}_{2}$ flow $=10 \mathrm{NLPH}(19.8$ grams per hour $)$

$\mathrm{H}_{2}$ flow $=30 \mathrm{NLPH}$ (2.67 grams per hour)

$\mathrm{N}_{2}$ flow (internal standard for GC analysis) $=0.8 \mathrm{NLPH}$ (1 grams per hour)

Mass of catalyst charged $=5 \mathrm{~g}$

$W H S V=(19.8+2.67+1) / 5=4.69 \mathrm{~h}^{-1}=\sim 4.7 \mathrm{~h}^{-1}$

$50 \mathrm{NLPH}:$

$\mathrm{CO}_{2}$ flow $=10 \mathrm{NLPH}$ (19.8 grams per hour) 
$\mathrm{H}_{2}$ flow $=40 \mathrm{NLPH}(3.56$ grams per hour $)$

$\mathrm{N}_{2}$ flow (internal standard for GC analysis) $=1 \mathrm{NLPH}$ (1.25 grams per hour)

Mass of catalyst charged $=5 \mathrm{~g}$

$W H S V=(19.8+3.56+1.25) / 5=4.922 \mathrm{~h}^{-1}=\sim 4.9 \mathrm{~h}^{-1}$

\subsection{Response factor of GC (RF):}

Response factor for a component ' $i$ ' of a detector is the ratio of peak area of component ' $i$ ' to calibration concentration (eqn. 1). The unknown concentration of component ' $\mathrm{i}$ ' during online gas analysis is determined multiplying response factor of component with peak area of the component obtained during online analysis. Note that calibration compositions of samples are expressed in percentage.

$R F i=$ Peak Area of $i \div$ Std. composition of $i$ in percentage

Unknown composition of $i$ in product gas (\%) $=R F \times$ Peak area of $i$ in product (2)

The GC RF for TCD are given below:

$\mathrm{RF}$ of $\mathrm{CO}_{2}=0.001617$

$\mathrm{RF}$ of $\mathrm{N}_{2}=0.001848$

$\mathrm{RF}$ of $\mathrm{CO}=0.00216$

$\mathrm{RF}$ of $\mathrm{CH}_{4}=0.00221$

\subsection{Conversion and product selectivity}

$\mathrm{CO}^{2}$ conversion in $\%=\left(\mathrm{CO}^{2}(\right.$ in $)-\mathrm{CO}^{2}($ out $\left.) \times \frac{\mathrm{N} 2(\text { out })}{\mathrm{N} 2(\text { in })}\right) \div \mathrm{CO}^{2}($ in $)$

Selectivity of $i=\left(100 n \times \operatorname{comp}\right.$ of $i / N^{2}($ out $\left.)\right) \div\left(\left(\frac{\text { CO2 (in })}{N 2(\text { in })}-\frac{\text { CO2(out })}{N 2(\text { out })}\right)\right.$

MeOH selectivity $(\%)=100-($ CO selectivity + CH4 selectivity $)$

$\mathrm{CO}_{2}($ in $)=$ composition of $\mathrm{CO}_{2}$ in feed gas

$\mathrm{CO}_{2}$ (out) $=$ composition of $\mathrm{CO}_{2}$ in product

$\mathrm{N}_{2}($ in $)=$ composition of $\mathrm{N}_{2}$ in feed gas

$\mathrm{N}_{2}$ (out) $=$ composition of $\mathrm{N}_{2}$ in product

\subsection{Liquid analysis}

The liquid products reaction is collected by condensation after 15 hours of reaction. The condensed liquid is analyzed for methanol by auto-liquid sampler of GC with FID as a detector. The liquid analysis is done by mixing $1.5 \mathrm{ml}$ of liquid product with $100 \mu \mathrm{l}$ of isopropyl alcohol (IPA). A calibration plot of different $\mathrm{MeOH}$ volume \% vs peak area ratio of $\mathrm{MeOH}$ to IPA is plotted by making different standards of $\mathrm{MeOH}-$ water mixture as shown in Figure below (Figure S5). The $\mathrm{MeOH}$ volume \% of unknown sample is determined from peak area ratio of $\mathrm{MeOH} / \mathrm{IPA}$ peak area by $\mathrm{GC}$. 
$\mathrm{MeOH}$ selectivity by gas analysis $=\left[100-\left(\mathrm{S}_{\mathrm{CO}}+\mathrm{S}_{\mathrm{CH} 4}\right)\right] \%$

\section{$\underline{\mathrm{Ni}}_{7} \underline{\operatorname{In}}_{3} \underline{\text { SBA-15-573K-50B-4.7 h-1 }}$}

Conversion $=17 \%$

CO selectivity $=\sim 12.75 \%$

$\mathrm{CH}_{4}$ selectivity $=0.4 \%$

From eqn (6), $\mathrm{MeOH}$ selectivity $=100-(12.75+0.4)=86.85 \%$

Out of 100 moles of product 86.85 moles are $\mathrm{MeOH}, 12.75$ are $\mathrm{CO}$ and negligible $0.4 \%$ are $\mathrm{CH}_{4}$.

$\mathrm{CO}_{2}+3 \mathrm{H}_{2} \rightarrow \mathrm{CH}_{3} \mathrm{OH}+\mathrm{H}_{2} \mathrm{O}$

$\mathrm{CO}_{2}+\mathrm{H}_{2} \rightarrow \mathrm{CO}+\mathrm{H}_{2} \mathrm{O}$

$\mathrm{CO}_{2}+4 \mathrm{H}_{2} \rightarrow \mathrm{CH}_{4}+2 \mathrm{H}_{2} \mathrm{O}$

MeOH mol \% in liquid product $=86.85 \times \frac{100}{86.85+86.85+12.75+0.8}$

Each mole of methanol and carbon monoxide gives one mole of water while each mole of methane gives 2 moles of water.

Thus, in liquid product $\mathrm{MeOH} \mathrm{mol} \%=46.4 \%$

$\mathrm{MeOH}$ weight $\%$ in liqd. $=(100 \times 46.4 \times 32) \div((46.4 \times 32)+(53.6 \times 18))$

$\mathrm{MeOH}$ weight $\%$ in liqd. $=60.6 \%$

From density of methanol $\left(0.791 \mathrm{gml}^{-1}\right)$ and water $\left(1 \mathrm{gml}^{-1}\right)$,

$\mathrm{MeOH}$ vol. $\%$ in liqd. $=66.04 \%$ (expected volume $\%$ of Methanol in liquid by gas analysis)

The average peak area ratio is 6.24

MeOH vol. $\%$ in liqd. $=(6.24 \times 9.154)+0.246$

MeOH vol. $\%$ in liqd. $=57.37 \%$ (The value is lesser than expected by gas analysis, this may be due to evaporation losses of $\mathrm{MeOH}$ during liquid condensation)

Similarly, liquid analysis is presented in table below

\begin{tabular}{|l|l|l|}
\hline MeOH (PA) & IPA (PA) & MeOH/IPA \\
\hline 2995 & 464 & 6.45 \\
\hline 2890 & 462 & 6.25 \\
\hline 2895 & 464 & 6.24 \\
\hline
\end{tabular}

Refer Table S2 for liquid analysis

3. Electronic structure of intermediates along competing pathways of $\mathrm{CO}_{2}$ on $\mathrm{Ni}_{3}$ In (111) 
To shed light on the nature of bonding between intermediates and the catalyst, we examine the projected density of states (PDOS) of the first intermediates occurring along the formate and cis$\mathrm{COOH}$ pathways of $\mathrm{CO}_{2}$ reduction on the (111) surface of $\mathrm{Ni}_{3} \mathrm{In}$ : $b i-\mathrm{HCOO}^{*} \mathrm{Ni}_{3} \mathrm{In}$ and trans$\mathrm{COOH} * \mathrm{Ni}_{3} \mathrm{In}$, respectively. The PDOS of $b i-\mathrm{HCOO} * \mathrm{Ni}_{3} \mathrm{In}$ and trans-COOH$* \mathrm{Ni}_{3}$ In reveal the highest occupied molecular orbitals (HOMO) of the adsorbates lie close to the bottom of the 3d-bands of Ni. HOMO of *bi-HCOO exhibits a sharp peak close to $-3.5 \mathrm{eV}$, (similar to $\mathrm{HOMO}$ of $* \mathrm{CO}_{2}$ ) accompanied by another smaller peak at a slightly higher energy. The degeneracy in the HOMO peaks is because of charge transfer from the surface to the adsorbate (see Fig. S14), which is also evident from the Lowdin charges that show a reduction the occupancy of Ni-3d and In-5s orbitals and an increased occupancy of O-2p orbitals of both the O-atoms of HCOO (Table S4). Also, HOMO of biHCOO splits and broadens because of its covalent interaction with the In-5p and Ni-4p orbitals of the catalyst, which are in resonance. HOMO of *trans-COOH lies deeper in energy and resonates with $\mathrm{Ni}-3 \mathrm{~d}, \mathrm{Ni}-4 \mathrm{p}$ and In-5p orbitals of the surface. Lowdin charge analysis shows a charge transfer from the $\mathrm{Ni}_{3} \mathrm{In}$ surface to the adsorbate. We find a decrease in the number of electrons in $\mathrm{Ni}-3 \mathrm{~d}$ states due to transfer to C-2s and C-2p orbitals (Table S4).

\section{Tables}


Table S1. Catalytic performances of different catalyst with respect to the reaction condition.

\begin{tabular}{|c|c|c|c|c|c|}
\hline Catalyst & $\begin{array}{l}\text { Reaction } \\
\text { Condition }\end{array}$ & $\begin{array}{c}\text { Conversion } \\
(\%)\end{array}$ & $\begin{array}{c}\text { Selectivity } \\
\text { towards } \\
\text { MeOH (\%) }\end{array}$ & $\begin{array}{c}\text { Selectivity } \\
\text { Towards } \\
\text { CO }(\%) \\
\end{array}$ & $\begin{array}{c}\text { Selectivity } \\
\text { Towards } \\
\mathrm{CH}_{4}(\%) \\
\end{array}$ \\
\hline \multirow{2}{*}{ SBA-15 } & $573 \mathrm{~K}-20 \mathrm{~B}-4.7 / \mathrm{h}$ & $<0.001$ & - & 100 & - \\
\hline & $573 \mathrm{~K}-20 \mathrm{~B}-4.7 / \mathrm{h}$ & $<0.001$ & - & 100 & - \\
\hline \multirow{4}{*}{ Ni/SBA-15 } & $573 \mathrm{~K}-40 \mathrm{~B}-4.7 / \mathrm{h}$ & 60 & - & $<0.05$ & $>99.5$ \\
\hline & 573K-40B-4.9/h & 80 & - & $<0.05$ & $>99.5$ \\
\hline & $573 \mathrm{~K}-20 \mathrm{~B}-4.7 / \mathrm{h}$ & 50 & - & $<0.05$ & $>99.5$ \\
\hline & $573 \mathrm{~K}-20 \mathrm{~B}-4.9 / \mathrm{h}$ & 68 & - & $<0.05$ & $>99.5$ \\
\hline \multirow[t]{12}{*}{$\mathrm{Ni}_{3} \mathrm{In} / \mathrm{SBA}-15$} & 573K-50B-4.7/h & 17.5 & $87-88$ & $12-13$ & $<1$ \\
\hline & $573 \mathrm{~K}-40 \mathrm{~B}-4.7 / \mathrm{h}$ & 17 & 79 & 20 & 0.5 \\
\hline & 573K-40B-4.9/h & 14.8 & 63 & 36 & 0.55 \\
\hline & $523 \mathrm{~K}-40 \mathrm{~B}-4.7 / \mathrm{h}$ & 4.75 & 73 & 27 & - \\
\hline & $523 \mathrm{~K}-40 \mathrm{~B}-4.9 / \mathrm{h}$ & 6 & 83 & 17.8 & - \\
\hline & 573K-20B-4.7/h & $16-16.5$ & 75 & 23.8 & 0.04 \\
\hline & 573K-20B-4.9/h & 13 & 67 & 32 & 0.08 \\
\hline & $523 \mathrm{~K}-20 \mathrm{~B}-4.7 / \mathrm{h}$ & 4.5 & 83 & 17 & - \\
\hline & $523 \mathrm{~K}-20 \mathrm{~B}-4.9 / \mathrm{h}$ & 4 & 85 & 14 & - \\
\hline & $573 \mathrm{~K}-5 \mathrm{~B}-4.7 / \mathrm{h}$ & $<1$ & - & 100 & - \\
\hline & $573 \mathrm{~K}-10 \mathrm{~B}-4.7 / \mathrm{h}$ & $1-2$ & 1 & $99-100$ & - \\
\hline & $573 \mathrm{~K}-15 \mathrm{~B}-4.7 / \mathrm{h}$ & 15.8 & 75 & 13-14 & 2 \\
\hline \multirow{3}{*}{$\begin{array}{c}\mathrm{NiO}- \\
\mathrm{In}_{2} \mathrm{O}_{3} / \mathrm{SBA}-15\end{array}$} & 573K-50B-4.7/h & 9 & 75 & 24 & $<1$ \\
\hline & $573 \mathrm{~K}-40 \mathrm{~B}-4.7 / \mathrm{h}$ & 11 & 77 & 22 & $<1$ \\
\hline & $573 \mathrm{~K}-20 \mathrm{~B}-4.7 / \mathrm{h}$ & 10.5 & 85 & 14.5 & 0.5 \\
\hline
\end{tabular}

Table S2. Methanol selectivity by liquid analysis.

\begin{tabular}{|c|c|c|c|c|}
\hline Catalyst & $\begin{array}{c}\text { Reaction } \\
\text { condition }\end{array}$ & $\begin{array}{c}\text { MeOH vol.\% } \\
\text { by gas analysis }\end{array}$ & $\begin{array}{c}\text { Ratio of } \\
\text { MeOH/IPA }\end{array}$ & $\begin{array}{c}\text { MeOH vol. \% by } \\
\text { liquid analysis }\end{array}$ \\
\hline $\mathrm{Ni}_{7} \mathrm{In}_{3} / \mathrm{SBA}-15$ & $573 \mathrm{~K}-50 \mathrm{~B}-4.7 / \mathrm{h}$ & 66.04 & 6.24 & 57.47 \\
\cline { 2 - 5 } & $573 \mathrm{~K}-40 \mathrm{~B}-4.7 / \mathrm{h}$ & 63.96 & 5.76 & 53.03 \\
\cline { 2 - 5 } & $573 \mathrm{~K}-20 \mathrm{~B}-4.7 / \mathrm{h}$ & 63.18 & 5.98 & 54.98 \\
\cline { 2 - 5 } & $573 \mathrm{~K}-40 \mathrm{~B}-4.9 / \mathrm{h}$ & 58.58 & 5.55 & 51.05 \\
\cline { 2 - 5 } & $573 \mathrm{~K}-20 \mathrm{~B}-4.9 / \mathrm{h}$ & 55.04 & 5.16 & 47.46 \\
\cline { 2 - 5 } & $523 \mathrm{~K}-40 \mathrm{~B}-4.7 / \mathrm{h}$ & 61.76 & 4.66 & 42.81 \\
\cline { 2 - 5 } & $523 \mathrm{~K}-20 \mathrm{~B}-4.7 / \mathrm{h}$ & 65.10 & 6.03 & 55.45 \\
\cline { 2 - 5 } & $523 \mathrm{~K}-40 \mathrm{~B}-4.9 / \mathrm{h}$ & 65.1 & 6.02 & 55.36 \\
\cline { 2 - 5 } & $523 \mathrm{~K}-20 \mathrm{~B}-4.9 / \mathrm{h}$ & 65.1 & 5.19 & 47.77 \\
\hline \multirow{5}{*}{$\mathrm{In}_{2} \mathrm{O}_{3} / \mathrm{SBA}-15$} & $573 \mathrm{~K}-50 \mathrm{~B}-4.7 / \mathrm{h}$ & 62.65 & 5.77 & 53.11 \\
\cline { 2 - 5 } & $573 \mathrm{~K}-40 \mathrm{~B}-4.7 / \mathrm{h}$ & 63.15 & 6.33 & 58.17 \\
\cline { 2 - 5 } & $573 \mathrm{~K}-20 \mathrm{~B}-4.7 / \mathrm{h}$ & 65.53 & 6.21 & 57.1 \\
\hline
\end{tabular}

Table S3. Summary of Ni $2 p$ XPS spectrum of $\mathrm{Ni}_{7} \mathrm{In}_{3} / \mathrm{SBA}-15$ and $\mathrm{Ni}_{3} \mathrm{In} / \mathrm{SBA}-15$ 


\begin{tabular}{|c|c|c|c|c|}
\hline Chemical State & \multicolumn{2}{|c|}{$\mathbf{N i}_{7} \mathbf{I n}_{\mathbf{3}} / \mathbf{S B A - 1 5}$} & \multicolumn{2}{c|}{$\mathbf{N i}_{3} \mathbf{I n} / \mathbf{S B A}-\mathbf{1 5}$} \\
\hline & $\begin{array}{c}\text { Binding } \\
\text { Energy }(\mathbf{e V})\end{array}$ & Peak Area & $\begin{array}{c}\text { Binding Energy } \\
(\mathbf{e V})\end{array}$ & Peak area \\
\hline $\mathrm{Ni}^{2+} 2 \mathrm{p}_{3 / 2}$ & 855.69 & 23566 & 856.462 & 10000 \\
\hline $\mathrm{Ni}^{2+} 2 \mathrm{p}_{1 / 2}$ & 873.055 & 6554 & 874.379 & 5932.2 \\
\hline $\mathrm{Ni}^{0} 2 \mathrm{p}_{3 / 2}$ & 851.627 & 5764.3 & 852.11 & 4734.8 \\
\hline $\mathrm{Ni}^{0} 2 \mathrm{p}_{1 / 2}$ & 869.318 & 2566.8 & 870.493 & 3483.2 \\
\hline
\end{tabular}

Table S4. Calculated Lowdin charges of $\mathrm{Ni}, \mathrm{In}, \mathrm{C}$ and $\mathrm{O}$ atoms for (a) pristine (111) surface of $\mathrm{Ni}_{3} \mathrm{In}$, (b) isolated $\mathrm{CO}_{2}$ molecule, and (c) $\mathrm{CO}_{2}$, (d) bi-HCOO and (e) trans-COOH adsorbed on the (111) surface of $\mathrm{Ni}_{3} \mathrm{In}$, respectively.

\begin{tabular}{|c|c|c|c|c|c|c|}
\hline \multirow[t]{2}{*}{ Sample } & \multirow[t]{2}{*}{ Atom } & \multicolumn{3}{|c|}{$\begin{array}{c}\text { Number of Valence } \\
\text { electrons }\end{array}$} & \multirow[t]{2}{*}{$\begin{array}{c}\text { Total number } \\
\text { of valence } \\
\text { electrons } \\
\end{array}$} & \multirow[t]{2}{*}{$\begin{array}{c}\text { Valence } \\
\text { configuration in } \\
\text { pseudopotential }\end{array}$} \\
\hline & & $\mathrm{S}$ & $\mathrm{p}$ & $\mathrm{d}$ & & \\
\hline \multirow{2}{*}{ (a) $\mathrm{Ni}_{3} \mathrm{In}$} & $\mathrm{Ni}$ & 0.42 & 0.99 & 8.8 & 10.21 & $4 s^{2} 3 d^{8}(10)$ \\
\hline & In & 0.8 & 1.46 & 9.94 & 12.2 & $5 s^{2} 4 d^{10} 5 p^{1}(13)$ \\
\hline \multirow{2}{*}{$\begin{array}{l}\text { (b) } \mathrm{CO}_{2} \\
\text { isolated }\end{array}$} & $\mathrm{C}$ & 0.74 & 2.46 & 0 & 3.2 & $2 s^{2} 2 p^{2}(4)$ \\
\hline & $\mathrm{O}$ & 1.66 & 4.61 & 0 & 6.27 & $2 s^{2} 2 p^{4}(6)$ \\
\hline \multirow{6}{*}{$\begin{array}{l}(\mathrm{c}) \mathrm{Ni}_{3} \mathrm{In} \\
\left(\mathrm{CO}_{2}\right. \\
\text { adsorbed })\end{array}$} & & & & & & $28^{2}$ \\
\hline & $\mathrm{N}_{1} \mathrm{C}$ & 0.42 & 1.09 & 8.76 & 10.21 & $4 s \quad 3 d(10)$ \\
\hline & $\mathrm{Ni}_{\mathrm{O}}$ & 0.4 & 1.03 & 8.72 & 10.15 & $4 s^{2} 3 d^{8}(10)$ \\
\hline & $\mathrm{C}$ & 0.88 & 2.61 & 0 & 3.49 & $2 s^{2} 2 p^{2}(4)$ \\
\hline & $\mathrm{O}$ & 1.63 & 4.64 & 0 & 6.27 & $2 s^{2} 2 p^{4}(6)$ \\
\hline & In & 0.79 & 1.44 & 9.94 & 12.17 & $5 s^{2} 4 d^{10} 5 p^{1}(13)$ \\
\hline \multirow{5}{*}{$\begin{array}{l}\text { (d) } \mathrm{Ni}_{3} \mathrm{In} \\
\text { (bi-HCOO } \\
\text { adsorbed) }\end{array}$} & $\mathrm{Ni}_{3}$ & & & & & 28 \\
\hline & ${ }^{1} \mathrm{I}_{01}$ & 0.4 & 1.06 & 8.72 & 10.18 & $4 \mathrm{~s}^{3} \mathrm{~d}(10)$ \\
\hline & $\mathrm{In}_{\mathrm{O} 2}$ & 0.73 & 1.43 & 9.95 & 12.11 & $5 s^{2} 4 d^{10} 5 p^{1}(13)$ \\
\hline & O1 & 1.66 & 4.73 & 0 & 6.39 & $2 s^{2} 2 p^{4}(6)$ \\
\hline & $\mathrm{O} 2$ & 1.61 & 4.71 & 0 & 6.32 & $2 s^{2} 2 p^{4}(6)$ \\
\hline \multirow{6}{*}{$\begin{array}{l}\text { (e) } \mathrm{Ni}_{3} \mathrm{In} \\
\text { (trans- } \\
\text { COOH } \\
\text { adsorbed) }\end{array}$} & & & & & & \\
\hline & $\mathrm{Ni}_{\mathrm{C}}$ & 0.4 & 1.19 & 8.72 & 10.34 & $4 s^{2} 3 d^{8}(10)$ \\
\hline & $\mathrm{Ni}_{\mathrm{O}}$ & 0.39 & 1.02 & 8.74 & 10.15 & $4 s^{2} 3 d^{8}(10)$ \\
\hline & $\mathrm{C}$ & 0.97 & 2.6 & 0 & 3.57 & $2 s^{2} 2 p^{2}(4)$ \\
\hline & $\mathrm{O}$ & 1.63 & 4.63 & 0 & 6.26 & $2 s^{2} 2 p^{4}(6)$ \\
\hline & In & 0.79 & 1.44 & 9.95 & 12.17 & $5 s^{2} 4 d^{10} 5 p^{1}(13)$ \\
\hline
\end{tabular}


Table S5. Important examples of intermetallic and bimetallic catalyst for $\mathrm{CO}_{2}$ hydrogenation to methanol.

\begin{tabular}{|c|c|c|c|c|c|}
\hline Catalyst & Synthesize route & Reaction Condition & $\begin{array}{l}\text { Conversio } \\
\text { n (\%) }\end{array}$ & $\begin{array}{l}\text { Selectivi } \\
\text { ty }(\%)\end{array}$ & Ref \\
\hline $\begin{array}{l}\mathrm{CuNi}_{2} / \mathrm{CeO}_{2} \\
\text { (bimetallic) }\end{array}$ & Impregnation & $\begin{array}{l}533 \mathrm{~K}, 30 \mathrm{bar} \text { and } \\
6000 \mathrm{~h}^{-1} \text { (GHSV). }\end{array}$ & 17.8 & 78 & 13 \\
\hline $\begin{array}{l}\text { PdIn IMC } \\
\text { NP }\end{array}$ & $\begin{array}{l}\text { Thermal } \\
\text { decomposition of } \\
\text { metal acetate in } \\
\text { squalane }\end{array}$ & $483 \mathrm{~K}$ and 50 bar. & 3 & 80 & 14 \\
\hline $\begin{array}{l}\mathrm{Pd}_{2} \mathrm{Ga} \\
\text { colloidal NP }\end{array}$ & $\begin{array}{l}\text { Colloidal synthesize } \\
\text { in CSTR } 300 \mathrm{ml} \text { Parr } \\
\text { reactor. }\end{array}$ & $483 \mathrm{~K}$ and $50 \mathrm{bar}$. & 3 & 75 & 15 \\
\hline $\begin{array}{l}\operatorname{In}: \operatorname{Pd}(2: 1) / \mathrm{Si} \\
\mathrm{O}_{2}\end{array}$ & $\begin{array}{l}\text { Incipient wetness } \\
\text { impregnation }\end{array}$ & $573 \mathrm{~K}$ and $50 \mathrm{bar}$ & $5.1 \mu \mathrm{mol} / \mathrm{g}$ & 61 & 16 \\
\hline $\mathrm{Cu}_{11} \mathrm{In}_{9} / \mathrm{In}_{2} \mathrm{O}$ & $\begin{array}{l}\mathrm{CuO}-\mathrm{In}_{2} \mathrm{O}_{3} \\
\text { heterostructure } \\
\text { reduced at } 623 \mathrm{~K}\end{array}$ & $553 \mathrm{~K}$ and 30 bar & 11.4 & 80.5 & 17 \\
\hline $\mathrm{Ni}_{5} \mathrm{Ga}_{3} / \mathrm{SiO}_{2}$ & $\begin{array}{l}\text { Incipient wetness } \\
\text { impregnation }\end{array}$ & $\begin{array}{l}493 \mathrm{~K} \text {, atm. Pressure } \\
\text { and } 6000 \mathrm{~h}^{-1} \text { (GHSV). }\end{array}$ & & $\begin{array}{l}\sim 0.25 \\
\mathrm{~mol} / \mathrm{hr}\end{array}$ & 18 \\
\hline
\end{tabular}




\section{Figures}

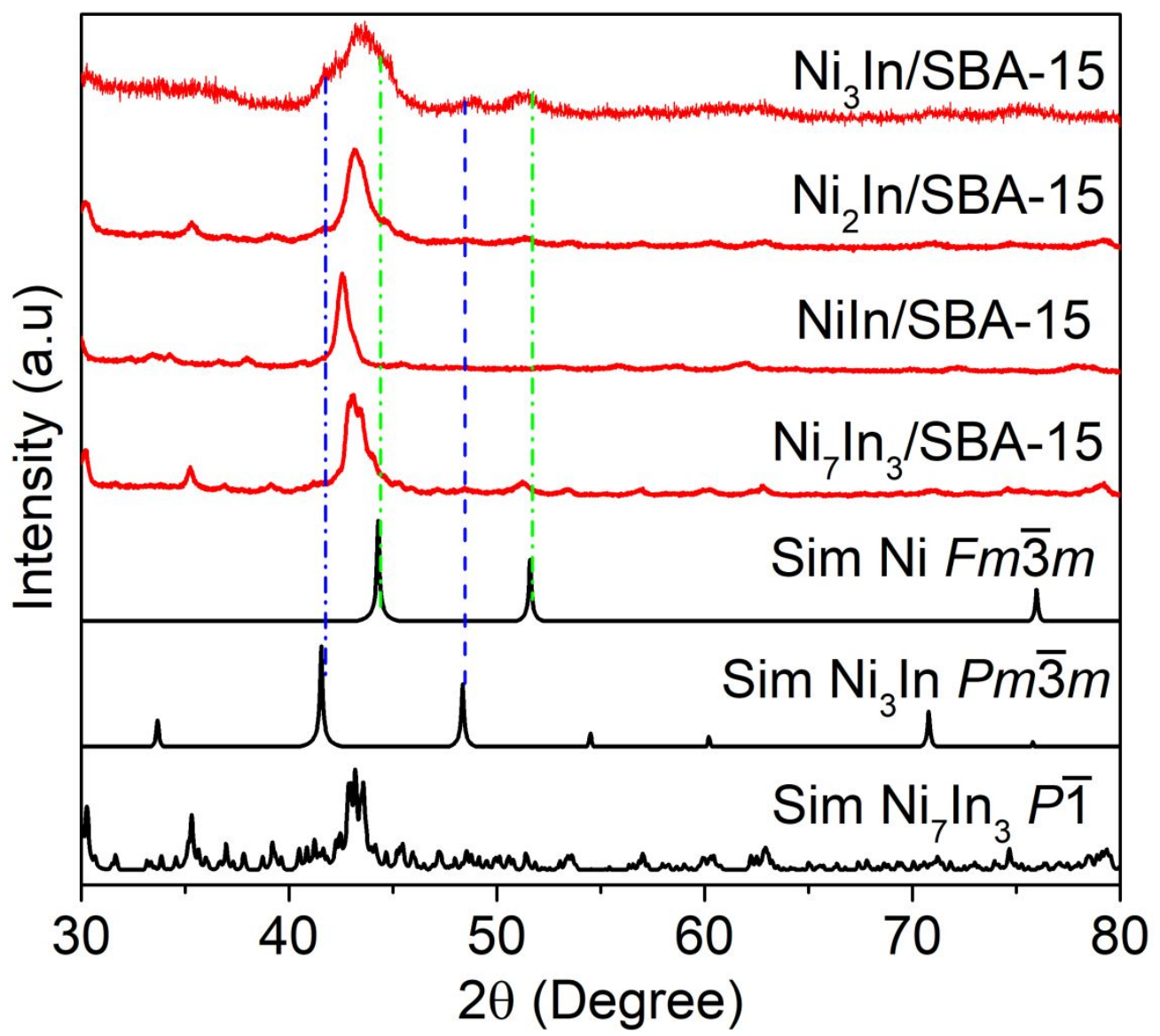

Figure S1. Powder XRD pattern of $\mathrm{Ni}_{3} \mathrm{In} / \mathrm{SBA}-15, \mathrm{Ni}_{2} \mathrm{In} / \mathrm{SBA}-15$, NiIn/SBA-15 Ni $\mathrm{In}_{3} / \mathrm{SBA}-$ 15, simulated Ni $F m \overline{3} m$, simulated $\mathrm{Ni}_{3} \operatorname{In} P m \overline{3} m$ and simulated $\mathrm{Ni}_{7} \operatorname{In}_{3} P \overline{1}$. 
a

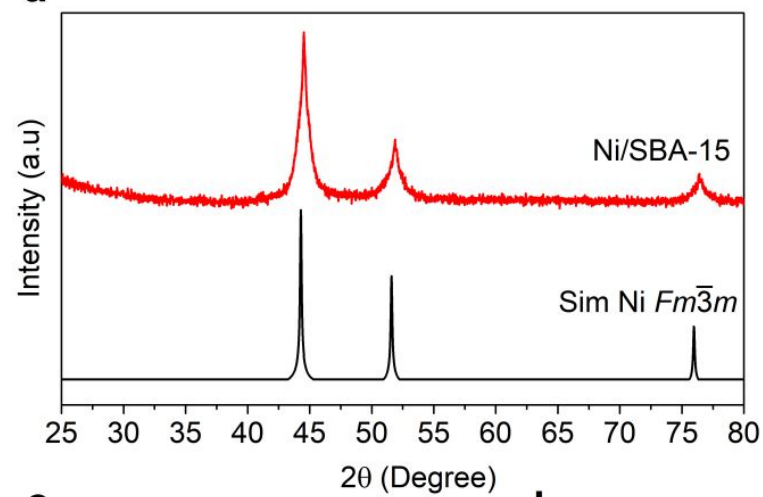

C

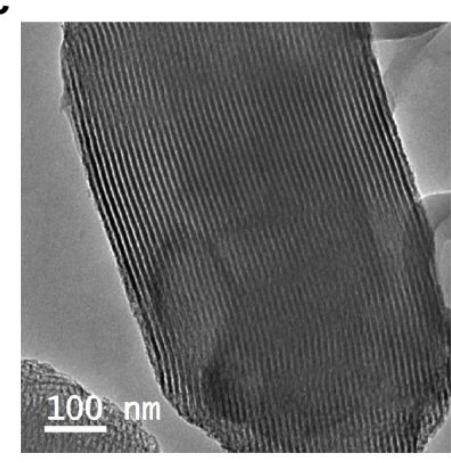

b

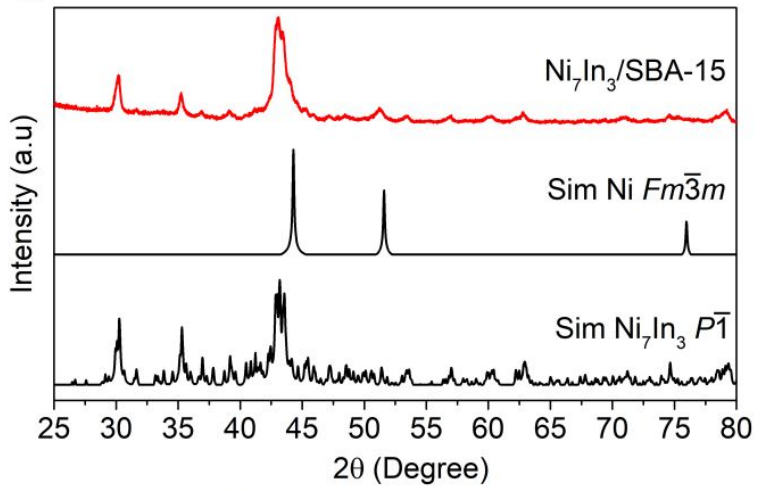

e
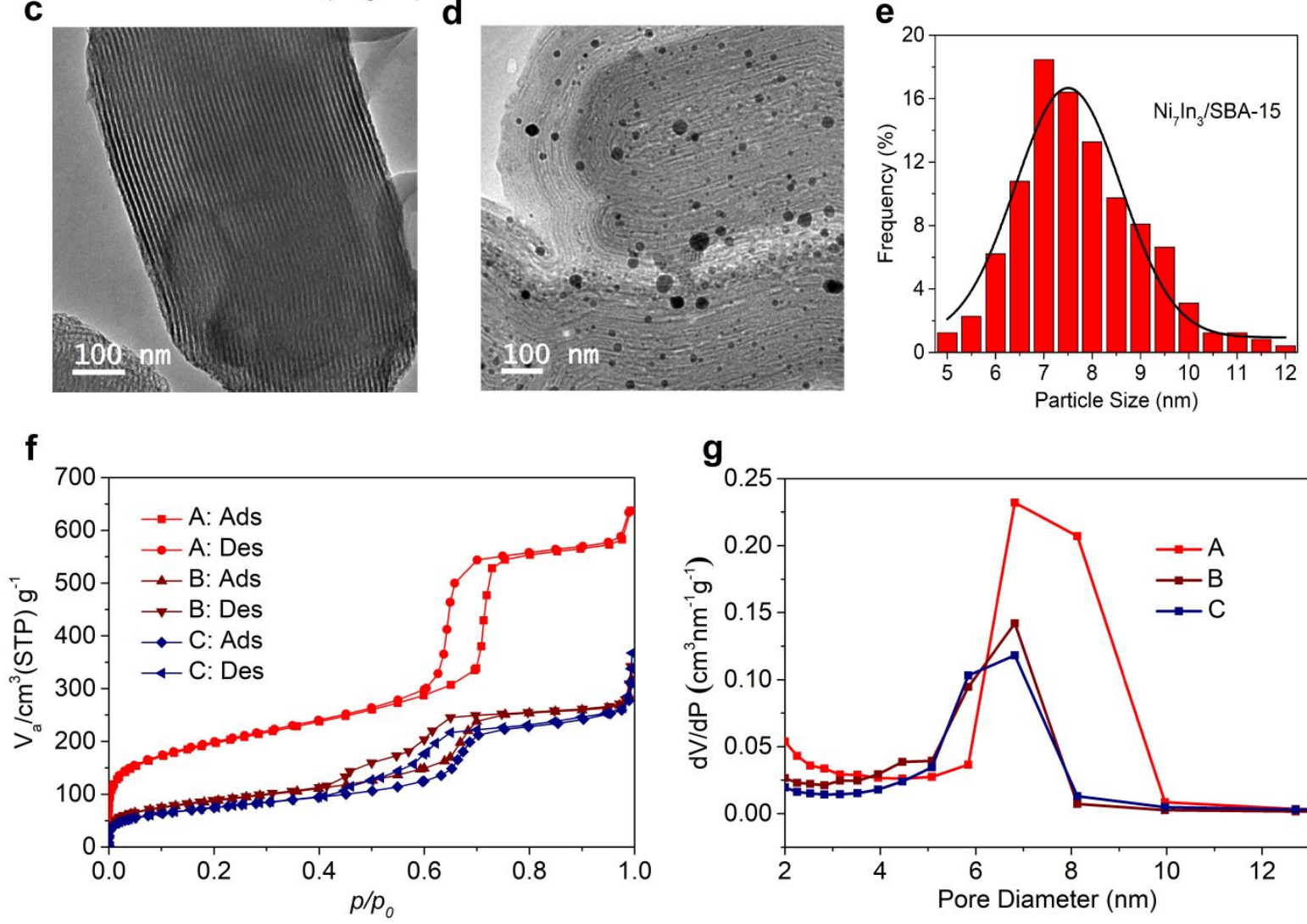

Figure S2. Powder XRD pattern comparison between experimental Ni/SBA-15 and simulated Ni (SG: $F m \overline{3} m$ ). b, Powder XRD pattern comparison between experimental $\mathrm{Ni}_{7} \mathrm{In}_{3} / \mathrm{SBA}-15$, simulated pattern of $\mathrm{Ni}$ (SG: $F m \overline{3} m$ ) and simulated pattern of $\mathrm{Ni}_{7} \mathrm{In}_{3}$ (SG: $P \overline{1}$ ). c, TEM image of SBA-15. d, TEM image of $\mathrm{Ni}_{7} \mathrm{In}_{3} / \mathrm{SBA}-15$. e, Particle size distribution of $\mathrm{Ni}_{7} \mathrm{In}_{3}$ on SBA-15. f, N2 adsorption-desorption isotherm of A: SBA-15, B: Ni/SBA-15 and $\mathrm{C}: \mathrm{Ni}_{7} \mathrm{In}_{3} / \mathrm{SBA}-15$ at $77 \mathrm{~K}$. g, corresponding pore size distribution by BJH method. 

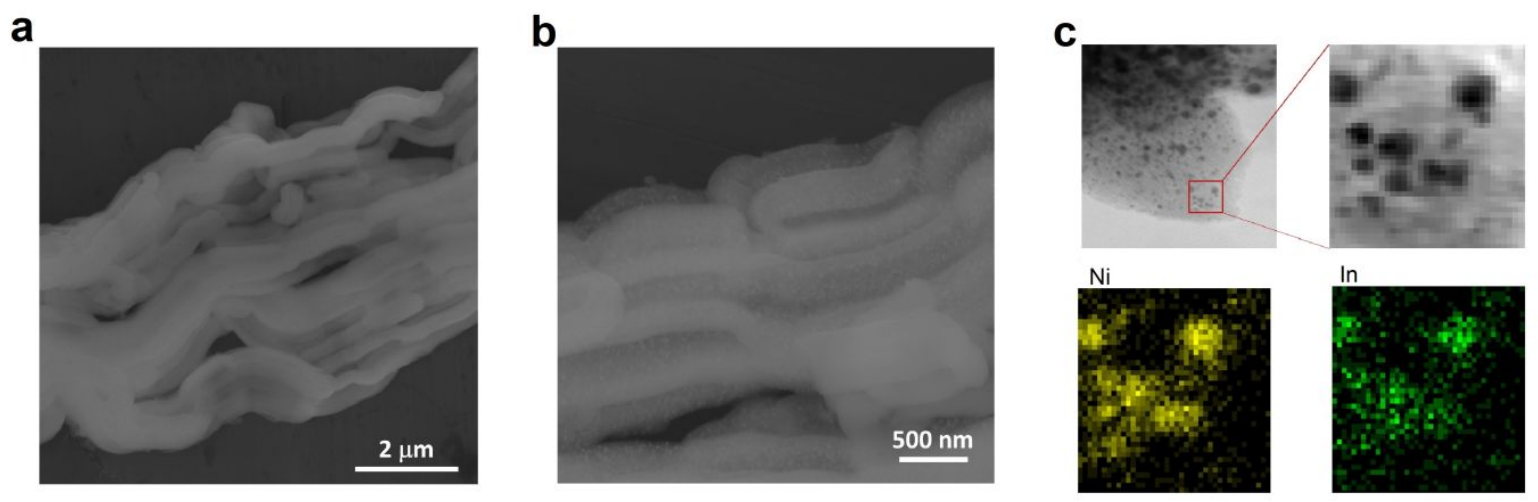

Figure S3. Material Characterization. a, SEM image of SBA-15. b, SEM image of $\mathrm{Ni}_{7} \mathrm{In}_{3} / \mathrm{SBA}-15$. c, STEM and elemental color mapping of nanoparticles,

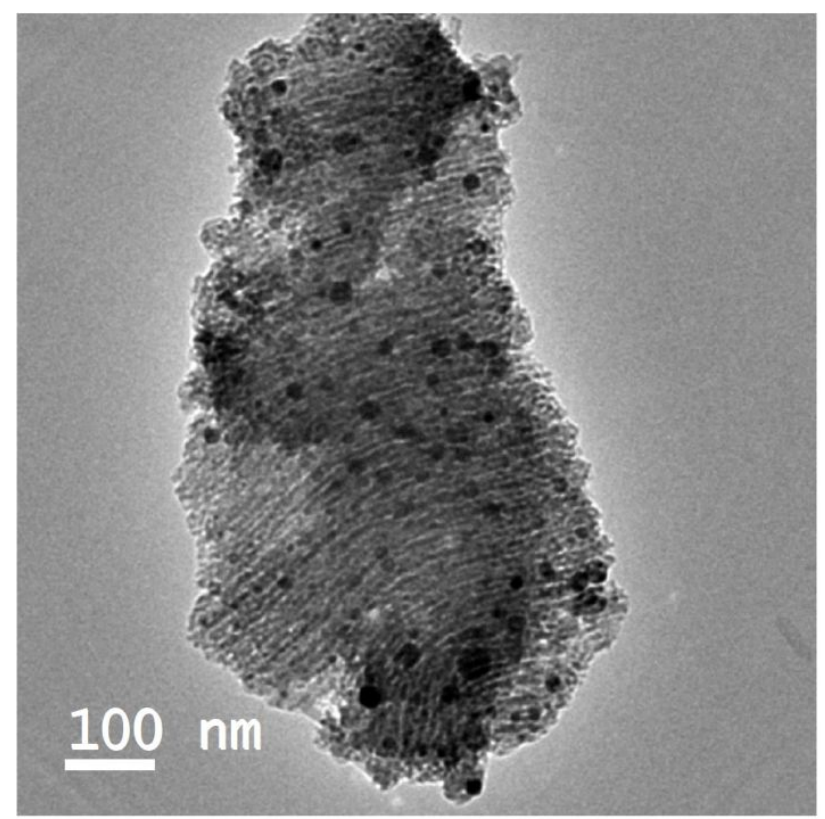

Figure S4. TEM image of Ni/SBA-15. 


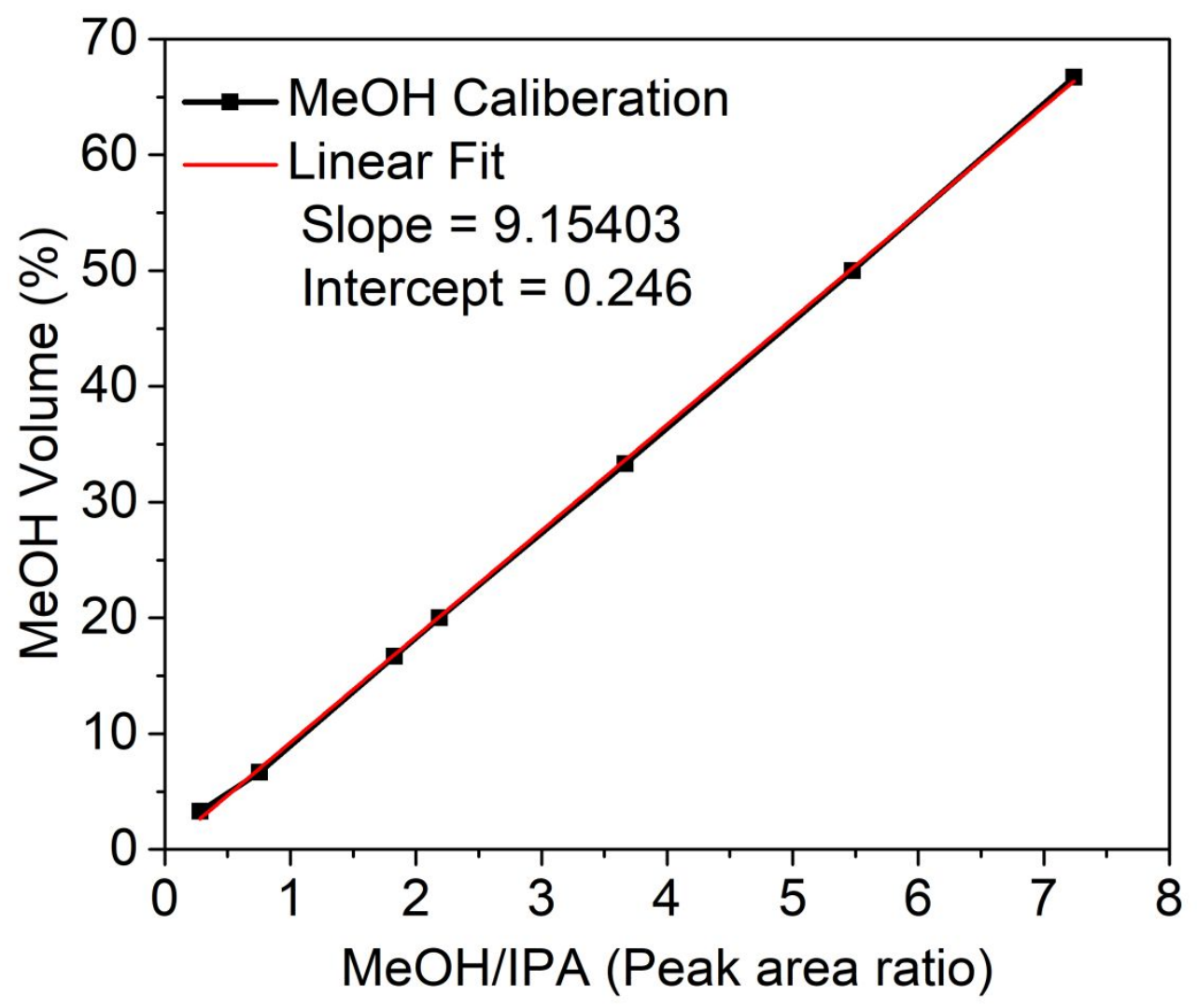

Figure S5. Calibration curve for liquid analysis 

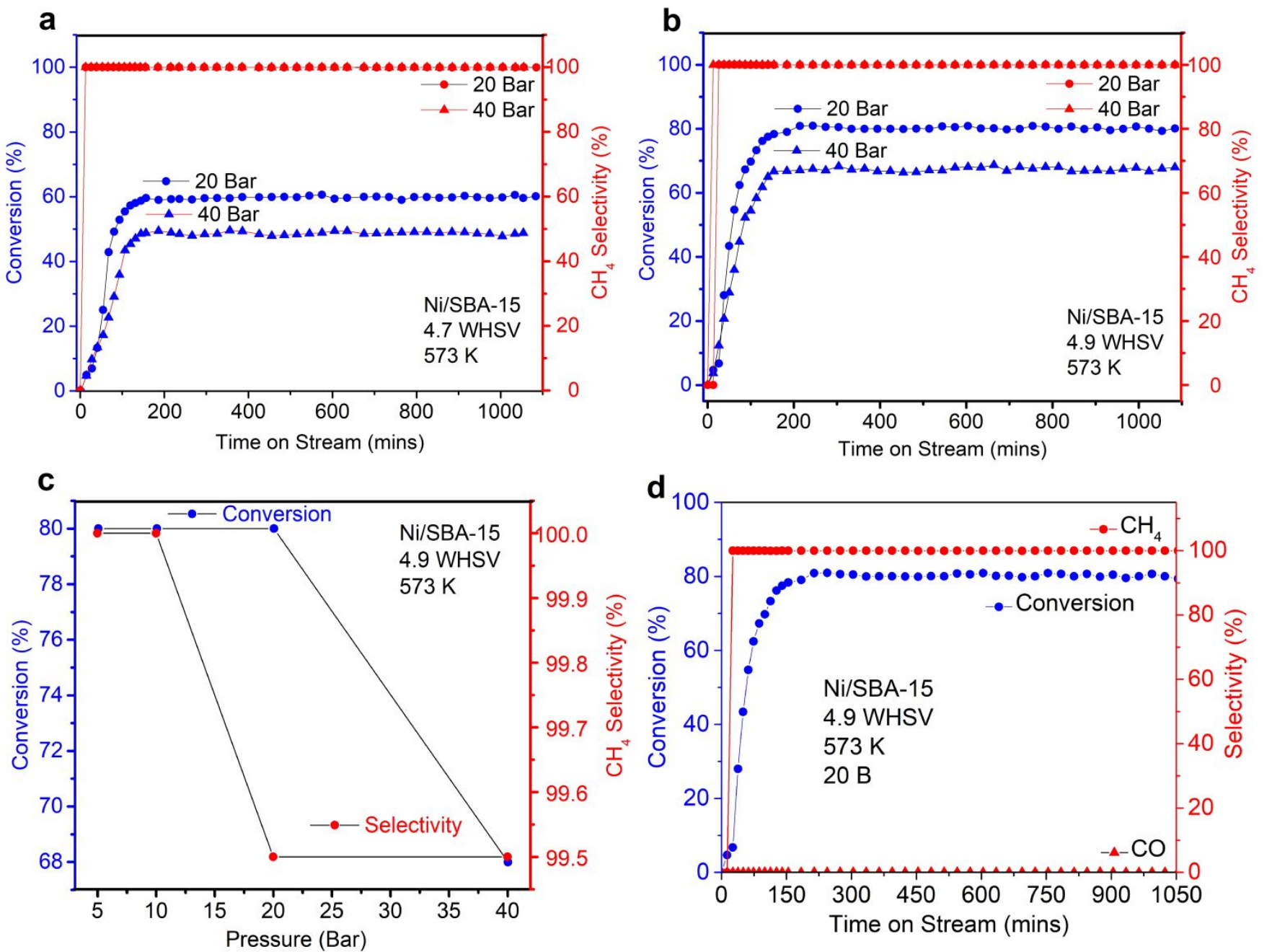

Figure S6. Catalytic performance of Ni/SBA-15. a, $\mathrm{CO}_{2}$ conversion and methane selectivity at reaction condition of 20 bar and 40 bar pressure with WHSV $4.7 \mathrm{~h}^{-1}\left(\mathrm{CO}_{2} / \mathrm{H}_{2}=1: 3\right)$ and at $573 \mathrm{~K}$ temperature. $\mathbf{b}, \mathrm{CO}_{2}$ conversion and methane selectivity at reaction condition of 20 bar and 40 bar with $4.9 \mathrm{~h}^{-1}\left(\mathrm{CO}_{2} / \mathrm{H}_{2}=1: 4\right)$ and $573 \mathrm{~K}$. c, $\mathrm{CO}_{2}$ conversion and methane selectivity at different pressures $\left(5-40\right.$ bar) with $4.9 \mathrm{~h}^{-1}$ and $573 \mathrm{~K}$. d, $\mathrm{CO}_{2}$ conversion and selectivity for 15 hours of time on stream at reaction condition of $4.9 \mathrm{~h}^{-1}, 20$ bar and $573 \mathrm{~K}$ 


\section{a}

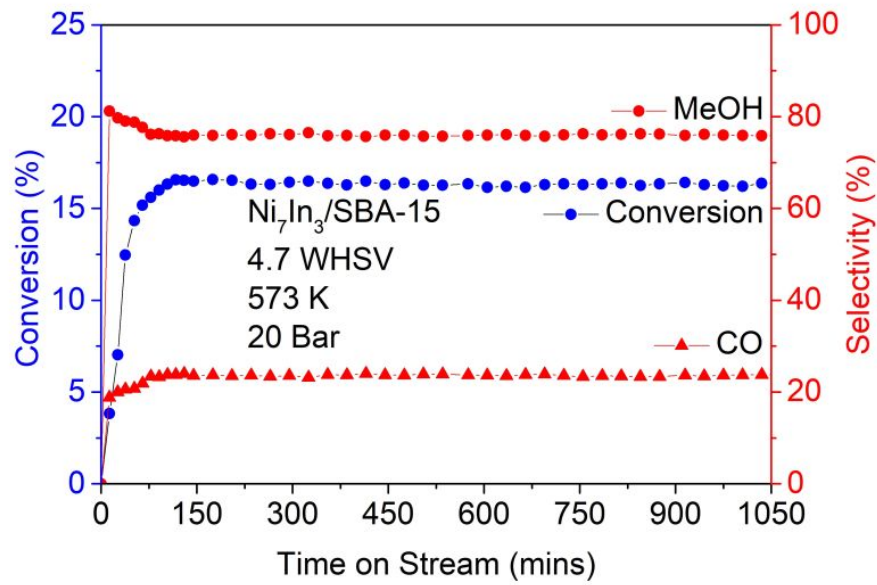

C

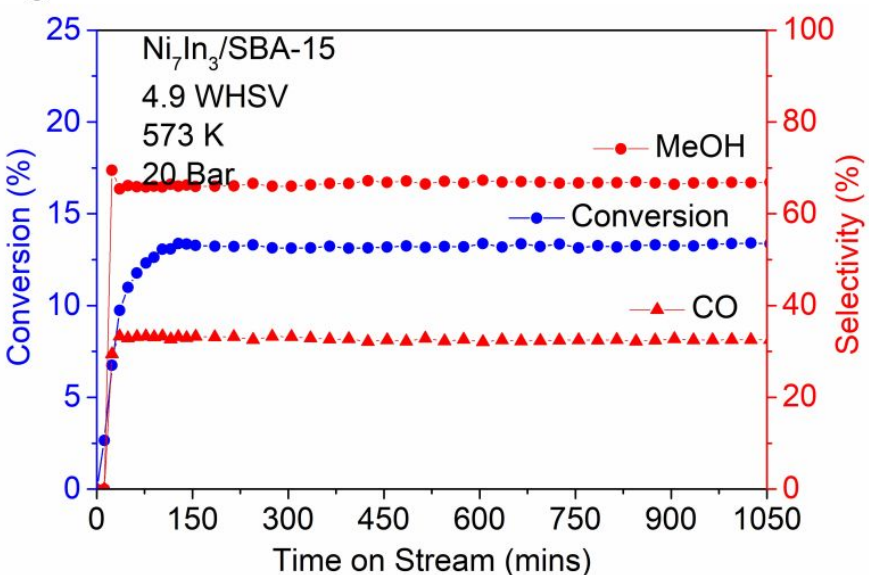

b

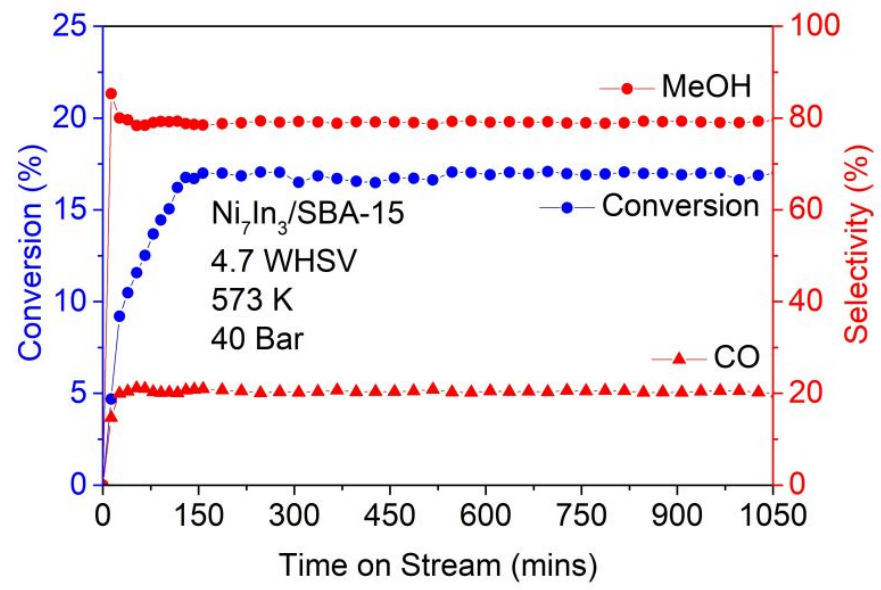

d

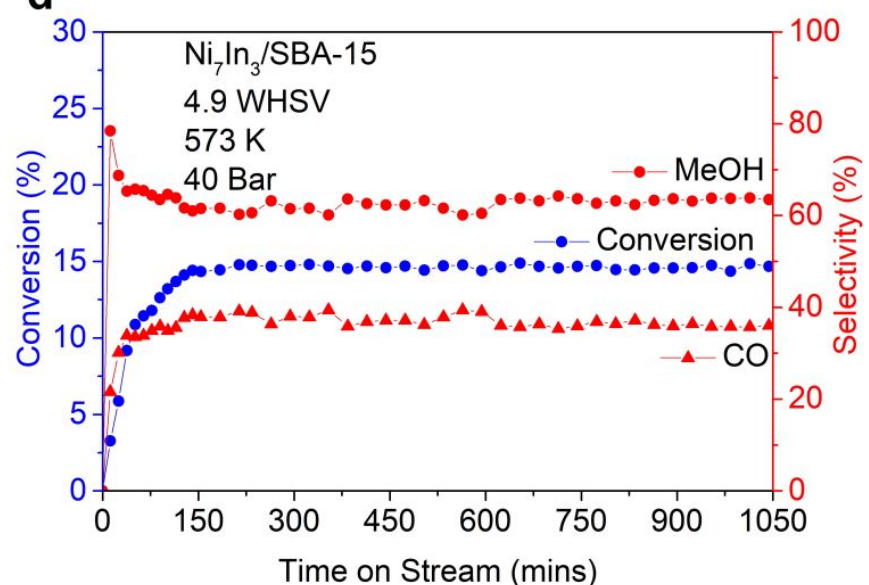

Figure S7. Catalytic test on $\mathrm{Ni}_{7} \mathrm{In}_{3} / \mathrm{SBA}-15$ at $573 \mathrm{~K}$. a, $\mathrm{CO}_{2}$ conversion and selectivity for 15 hours of time on stream at reaction condition of $4.7 \mathrm{~h}^{-1}(1: 3)$ and 20 bar. b, $\mathrm{CO}_{2}$ conversion and selectivity for 15 hours of time on stream at reaction condition of $4.7 \mathrm{~h}^{-1}(1: 3)$ and 40 bar. , $\mathrm{CO}_{2}$ conversion and selectivity for 15 hours of time on stream at reaction condition of $4.9 \mathrm{~h}^{-1}$ (1:4), and 20 bar. d, $\mathrm{CO}_{2}$ conversion and selectivity for 15 hours of time on stream at reaction condition of $4.9 \mathrm{~h}^{-1}(1: 4)$ and 40 bar. 

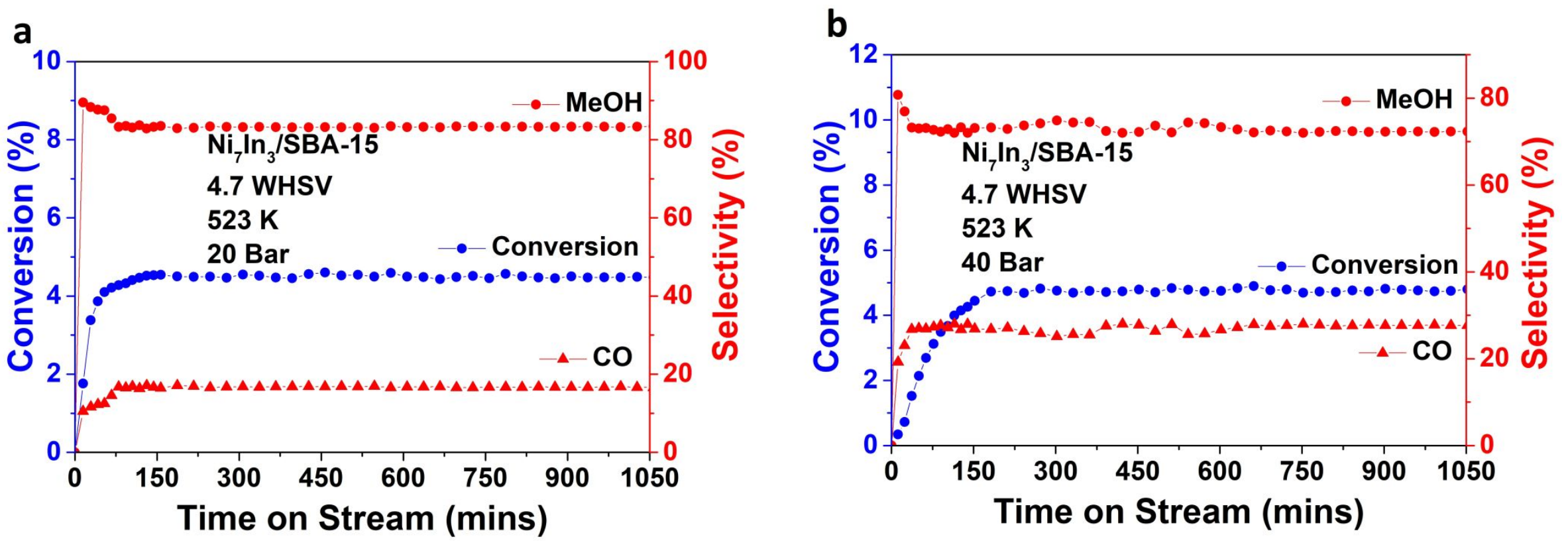

Figure S8. Catalytic test on $\mathrm{Ni}_{7} \mathrm{In}_{3} / \mathrm{SBA}-15$ at $523 \mathrm{~K}$. a, $\mathrm{CO}_{2}$ conversion and selectivity for 15 hours of time on stream at reaction condition of $4.7 \mathrm{~h}^{-1}(1: 3)$ and 20 bar. $\mathbf{b}, \mathrm{CO}_{2}$ conversion and selectivity for 15 hours of time on stream at reaction condition of $4.7 \mathrm{~h}^{-1}(1: 3)$ and $40 \mathrm{bar}$. 


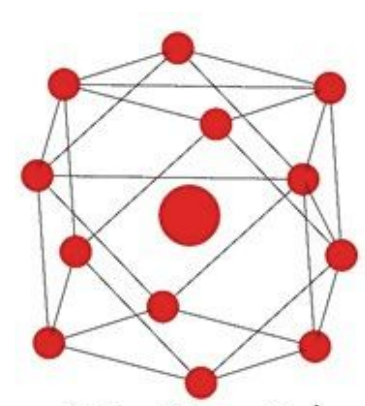

$\mathrm{Ni}$ in Ni metal

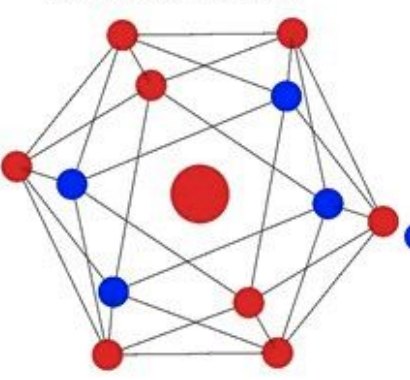

$\mathrm{Ni} 5$ in $\mathrm{Ni}_{7} \mathrm{In}_{3}$

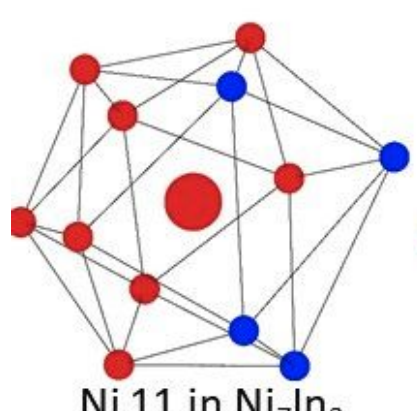

$\mathrm{Ni} 11$ in $\mathrm{Ni}_{7} \mathrm{In}_{3}$
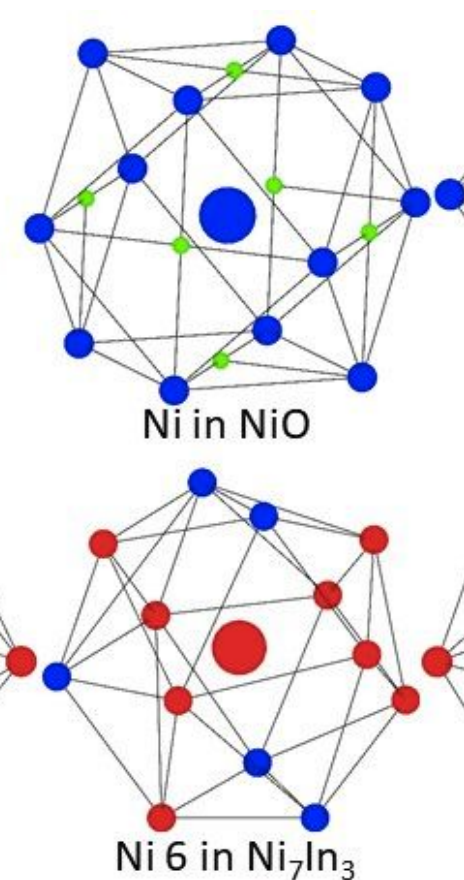

$\mathrm{Ni} 6$ in $\mathrm{Ni}_{7} \mathrm{In}_{3}$

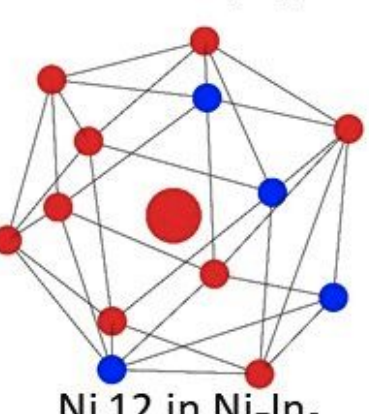

$\mathrm{Ni} 12$ in $\mathrm{Ni}_{7} \mathrm{In}_{3}$

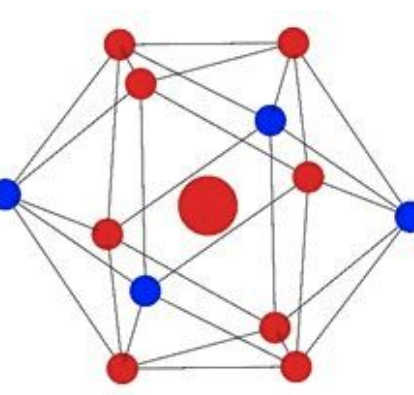

$\mathrm{Ni} 1$ in $\mathrm{Ni}_{7} \mathrm{ln}_{3}$

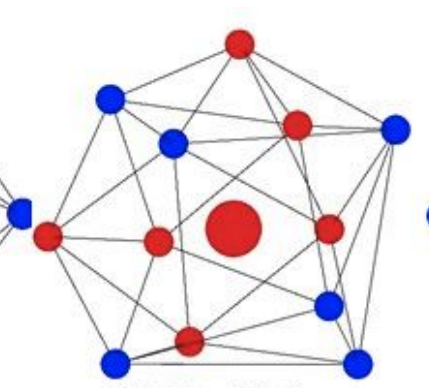

$\mathrm{Ni} 2$ in $\mathrm{Ni}_{7} \mathrm{In}_{3}$

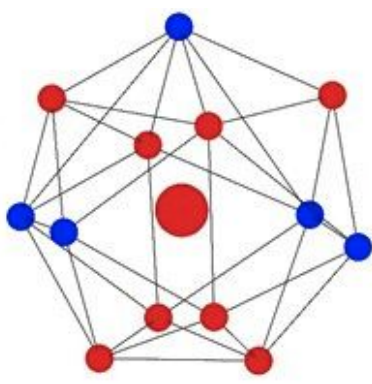

$\mathrm{Ni} 3$ in $\mathrm{Ni}_{7} \mathrm{In}_{3}$

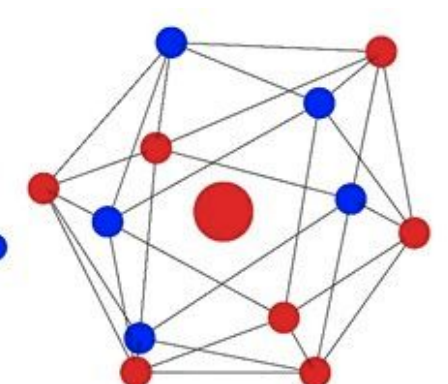

$\mathrm{Ni} 4$ in $\mathrm{Ni}_{7} \mathrm{In}_{3}$
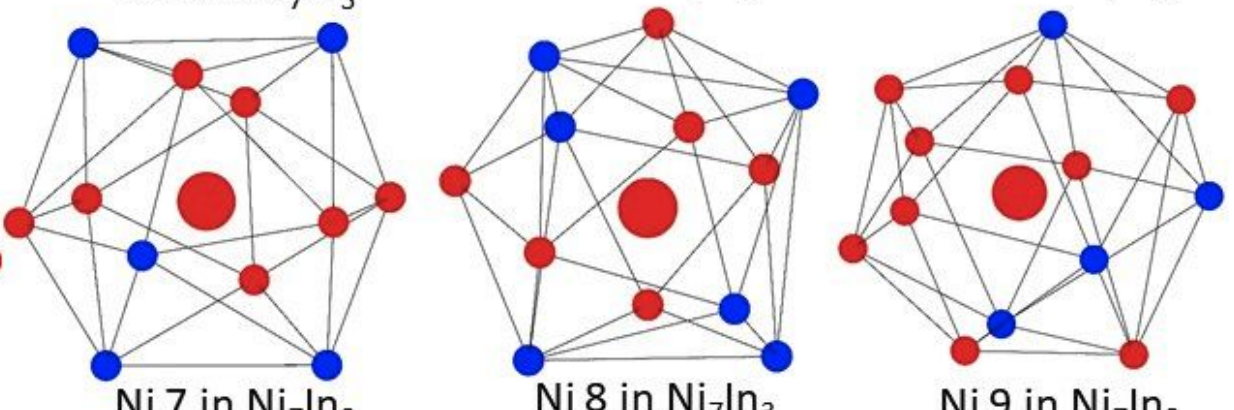

$\mathrm{Ni} 9$ in $\mathrm{Ni}_{7} \mathrm{In}_{3}$

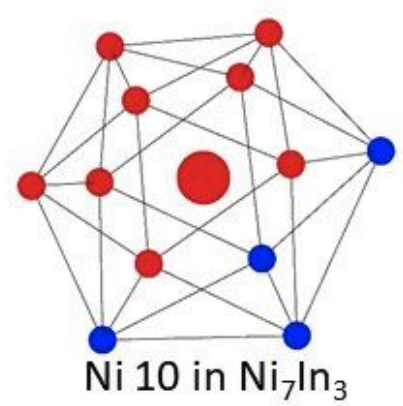

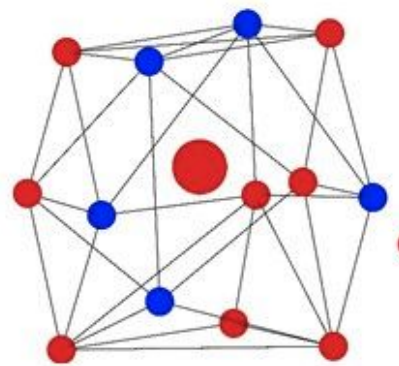

$\mathrm{Ni} 13$ in $\mathrm{Ni}_{7} \mathrm{In}_{3}$

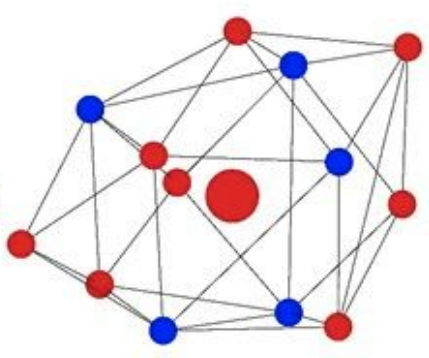

Ni 14 in $\mathrm{Ni}_{7} \mathrm{In}_{3}$

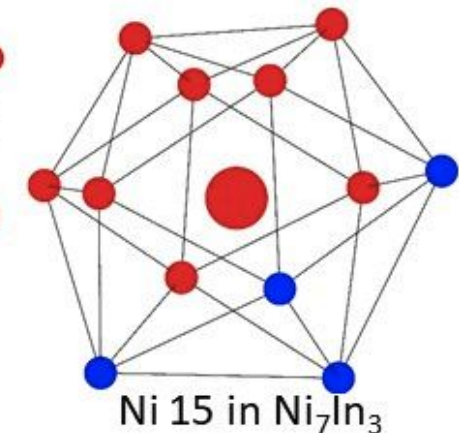

Figure S9. Coordination environment of $\mathrm{Ni}$ in $\mathrm{Ni}$ metal, $\mathrm{NiO}, \mathrm{Ni}_{7} \mathrm{In}_{3}$ and $\mathrm{Ni}_{3} \mathrm{In}_{\text {. }}$ 


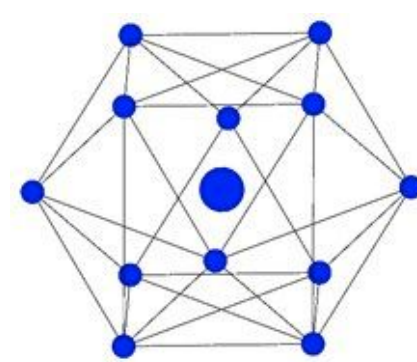

In in In Fmmm

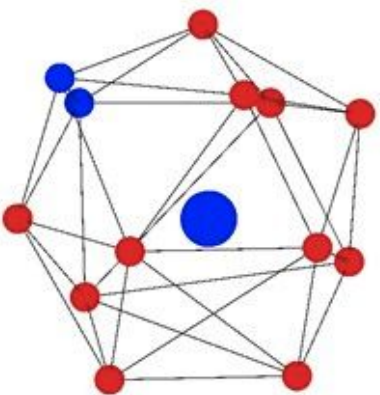

In 1 in $\mathrm{Ni}_{7} \mathrm{In}_{3}$

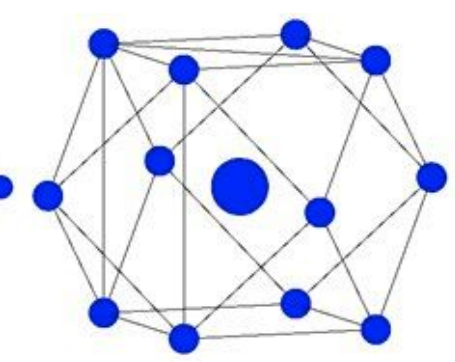

In in In $14 / \mathrm{mmm}$

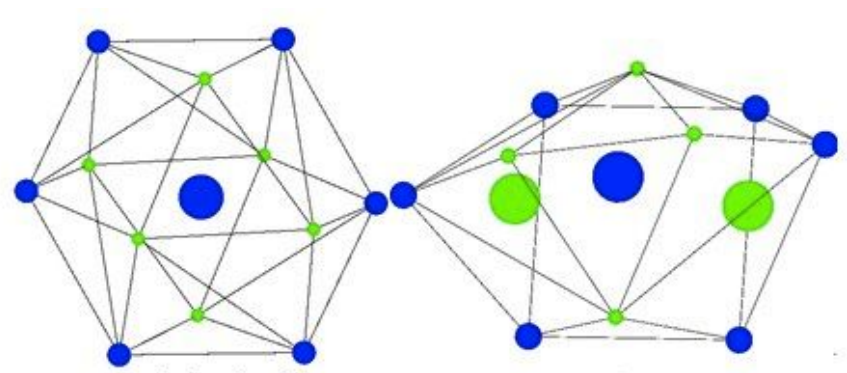

In 1 in $\ln _{2} \mathrm{O}_{3}$

In 2 in $\ln _{2} \mathrm{O}_{3}$
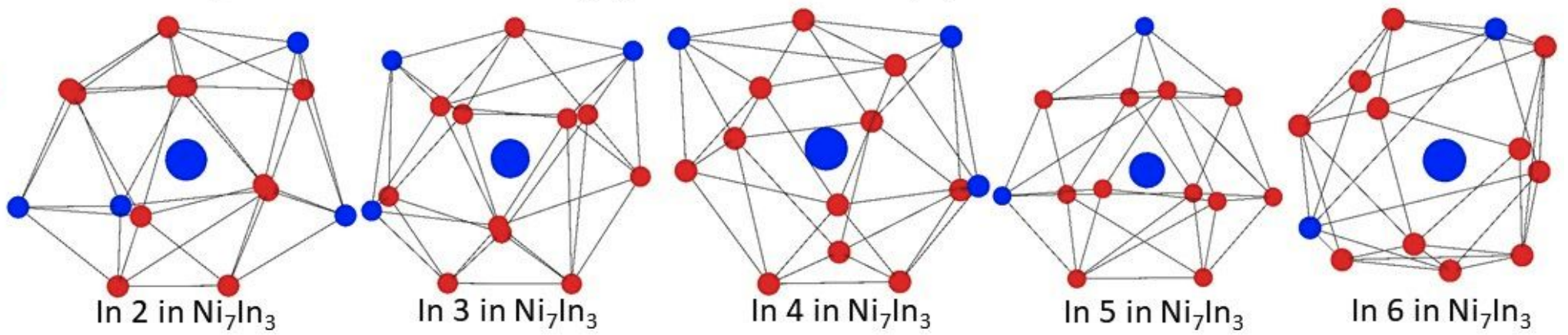

Figure S10. Coordination environment of In in In metal, Ni7In3, Ni3In and In2O3 


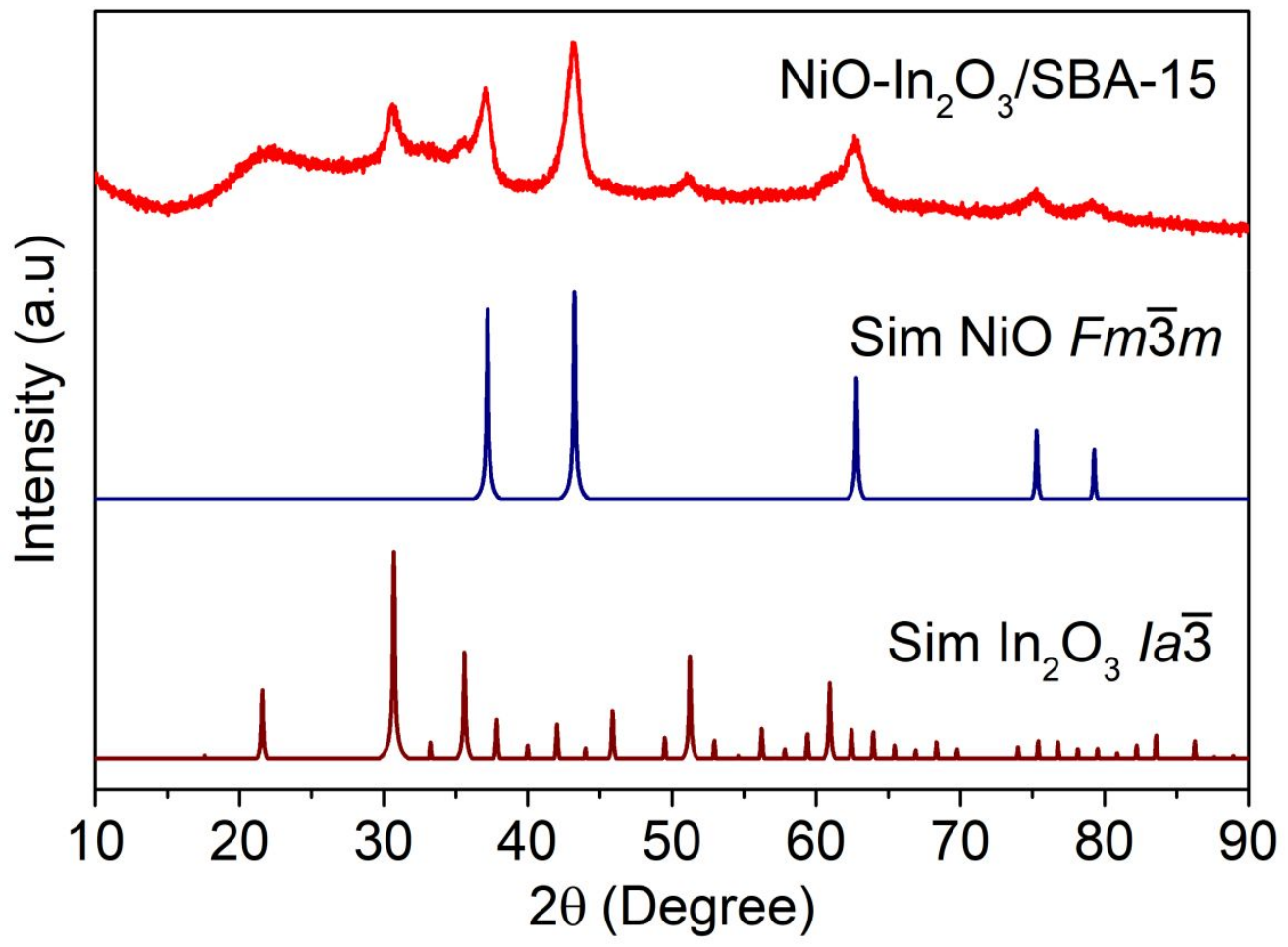

Figure S11. Powder XRD pattern of $\mathrm{NiO}-\mathrm{In}_{2} \mathrm{O}_{3} / \mathrm{SBA}-15$, simulated $\mathrm{NiO} F m \overline{3} m$ and simulated $\mathrm{In}_{2} \mathrm{O}_{3} \mathrm{Ia} \overline{3}$. 

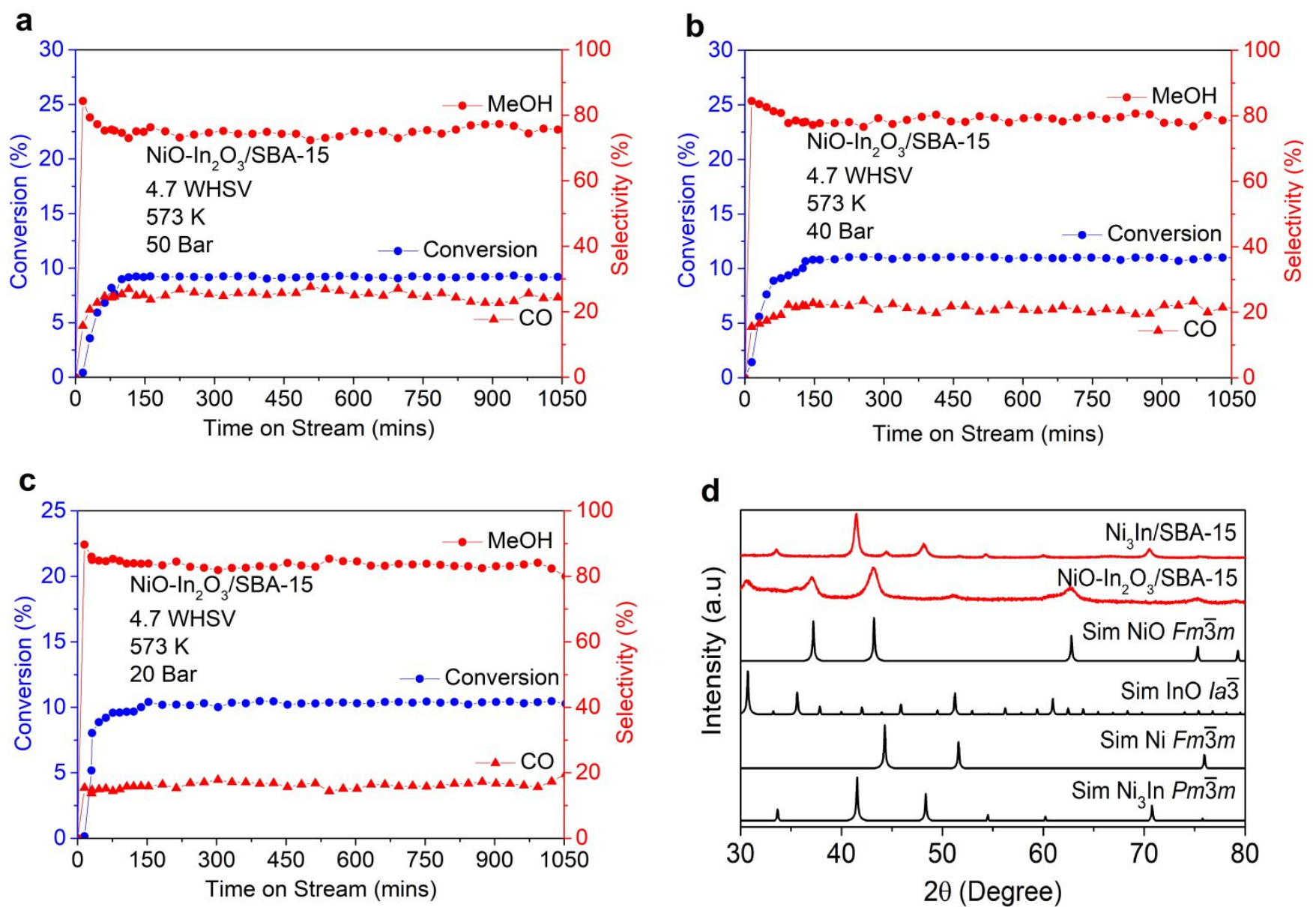

Figure S12. Catalytic performance of NiO- $\mathrm{In}_{2} \mathrm{O}_{3} / \mathrm{SBA}-15$ at $573 \mathrm{~K}$. a, $\mathrm{CO}_{2}$ conversion and selectivity for 15 hours of time on stream at reaction condition of $4.7 \mathrm{~h}^{-1}(1: 3)$ and 50 bar. $\mathbf{b}, \mathrm{CO}_{2}$ conversion and selectivity for 15 hours of time on stream at reaction condition of $4.7 \mathrm{~h}^{-1}$ (1:3) and 40 bar. $\mathbf{c}, \mathrm{CO}_{2}$ conversion and selectivity for 15 hours of time on stream at reaction condition of $4.7 \mathrm{~h}^{-1}$ (1:3) and 20 bar. d, Comparison of the powder XRD patterns of experimental $\mathrm{Ni}_{3} \mathrm{In} / \mathrm{SBA}-15$ and $\mathrm{NiO}-\mathrm{In}_{2} \mathrm{O}_{3} / \mathrm{SBA}-15$ with the simulated patterns of $\mathrm{NiO}(\mathrm{SG}: F m \overline{3} m)$, In $\mathrm{O}_{3}$

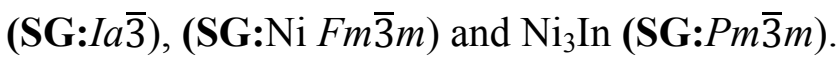




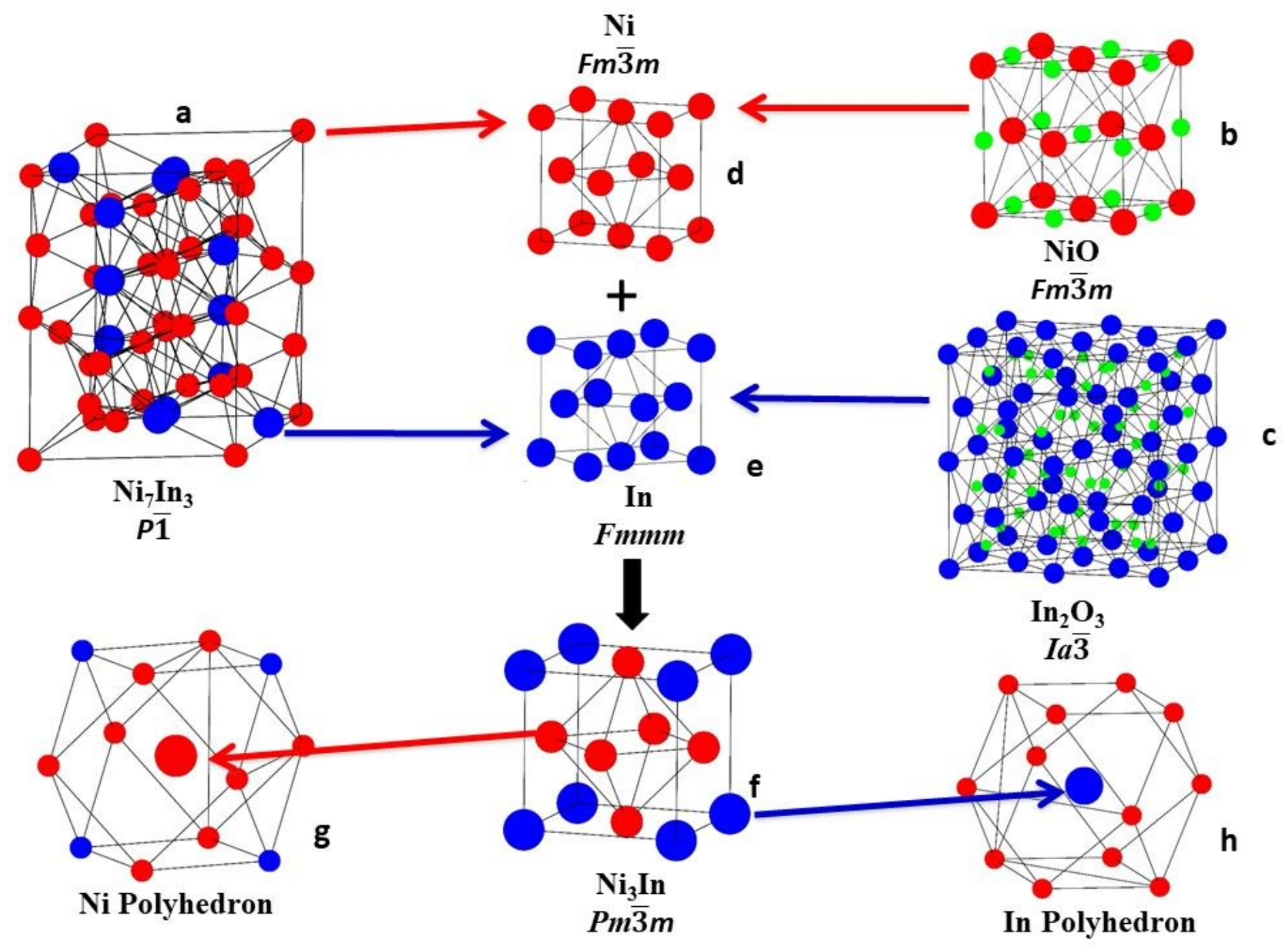

Figure S13. Operando structural phases transformation of different starting materials $\mathrm{Ni}_{7} \mathrm{In}_{3} / \mathrm{SBA}-15$ a, and $\mathrm{NiO}-\mathrm{In}_{2} \mathrm{O}_{3} / \mathrm{SBA}-15$ (b and c) to $\mathrm{Ni}_{3} \mathrm{In} / \mathrm{SBA}-15$ (f) through the intermediates $\mathrm{Ni}$ (d) and In (e) metals under $573 \mathrm{~K}$ and above 20 bar pressure. The coordination environment of Ni (g) and $\mathrm{In}(\mathrm{h})$ in $\mathrm{Ni}_{3}$ In structure. 

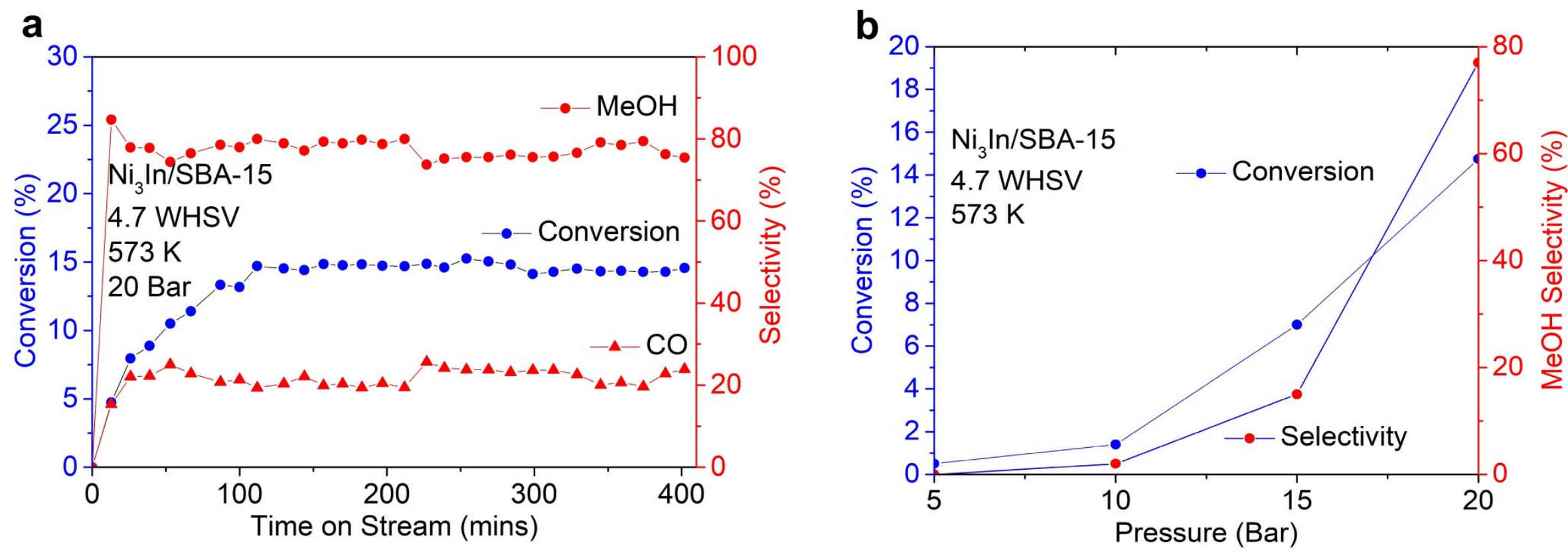

Figure S14. Catalytic performance of $\mathbf{N i}_{3} \mathbf{I n} / \mathbf{S B A}-15$. a, $\mathrm{CO}_{2}$ conversion and selectivity for 6 hours of time on stream at reaction condition of $4.7 \mathrm{~h}^{-1}(1: 3)$ and 20 bar. b, $\mathrm{CO}_{2}$ conversion and methanol selectivity at different pressures (5-20 bar) with $4.7 \mathrm{~h}^{-1}$ and $573 \mathrm{~K}$. 


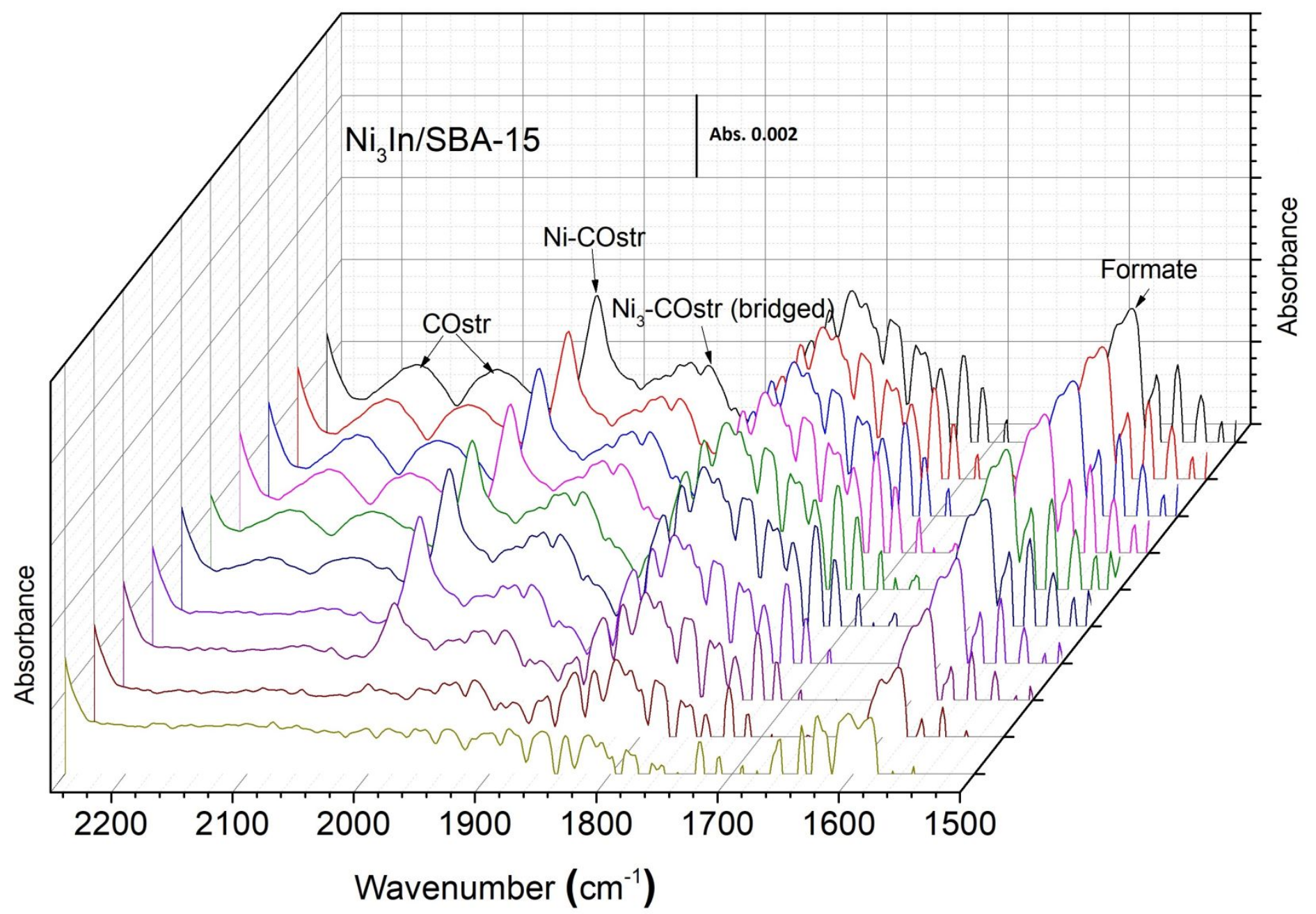

Figure S15. Successive DRIFTS spectra of formate and CO stretching regions over $\mathrm{Ni}_{3} \mathrm{In} / \mathrm{SBA}-15$ plotted against time over Ni ${ }_{3} \mathrm{In} / \mathrm{SBA}-15$. 


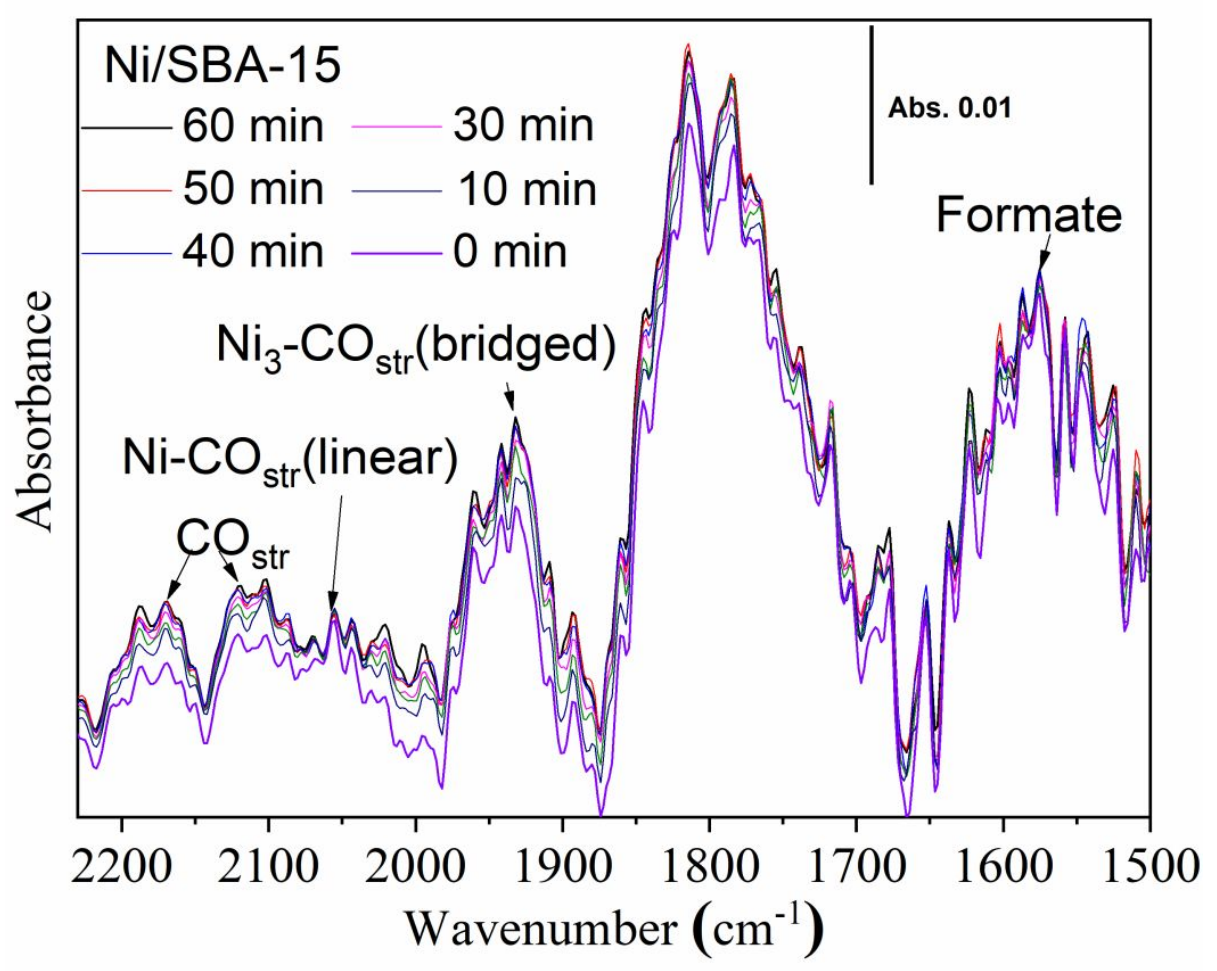

Figure S16. Successive DRIFTS spectra of formate and CO stretching regions over Ni/SBA15 for an hour on stream.

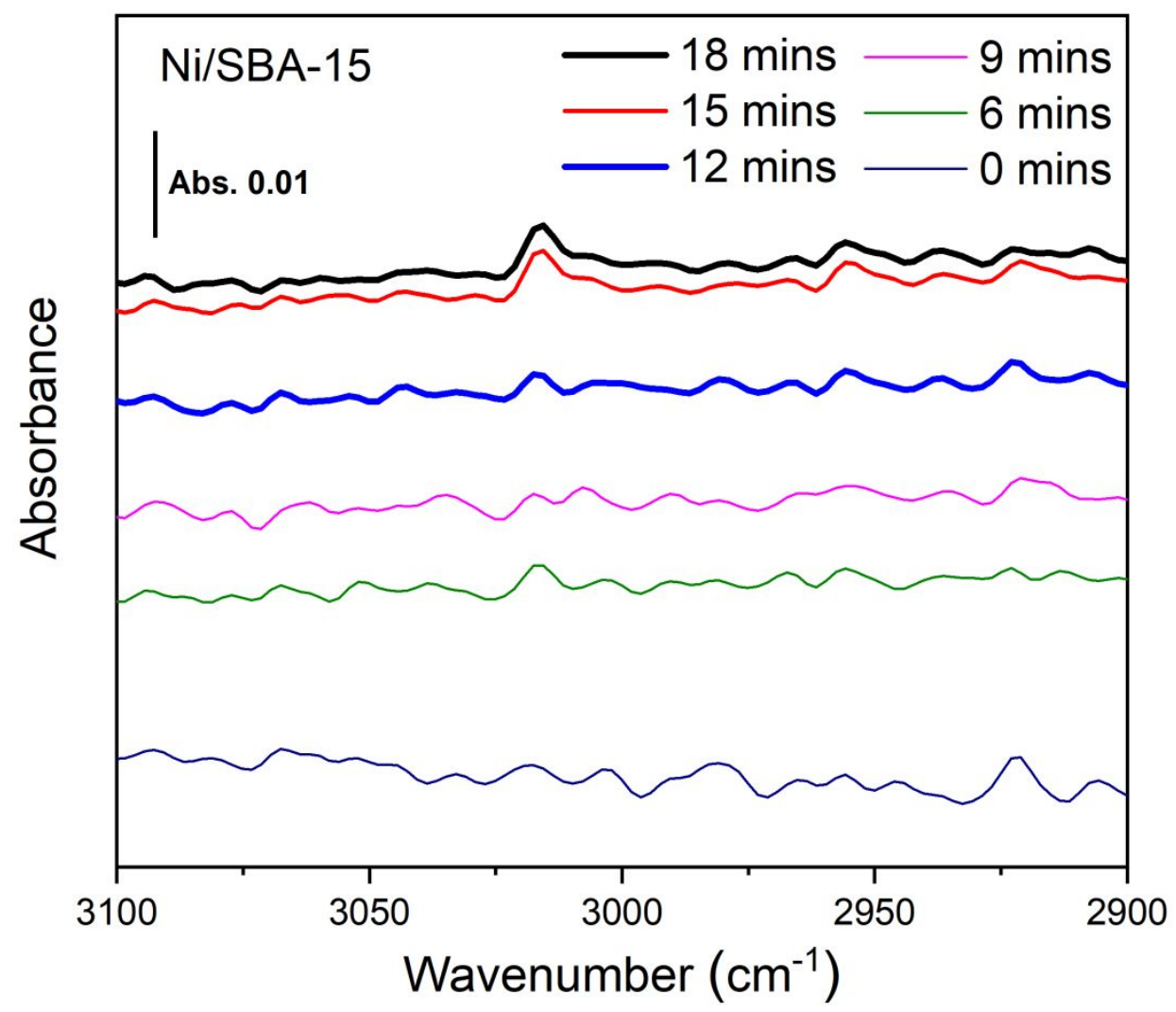

Figure S17. Successive spectra of CO stretching regions over Ni/SBA-15 plotted with time of temperature ramp from $303 \mathrm{~K}$ to $573 \mathrm{~K}$. 


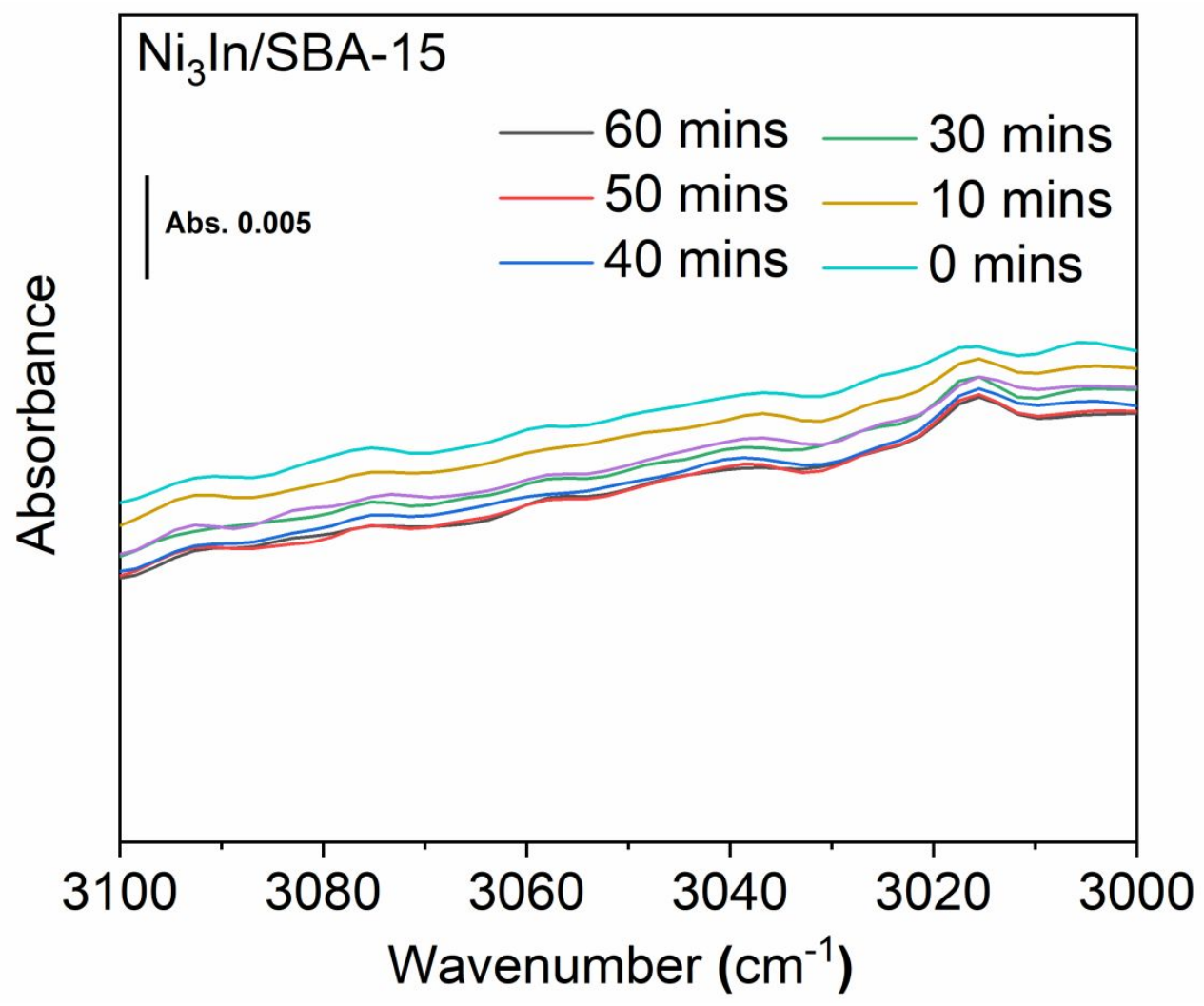

Figure S18. Successive DRIFTS spectra of $\mathrm{CH}_{\text {str }}$ stretching regions over $\mathrm{Ni}_{3} \mathrm{In} / \mathrm{SBA}-15$ for an hour on stream. 

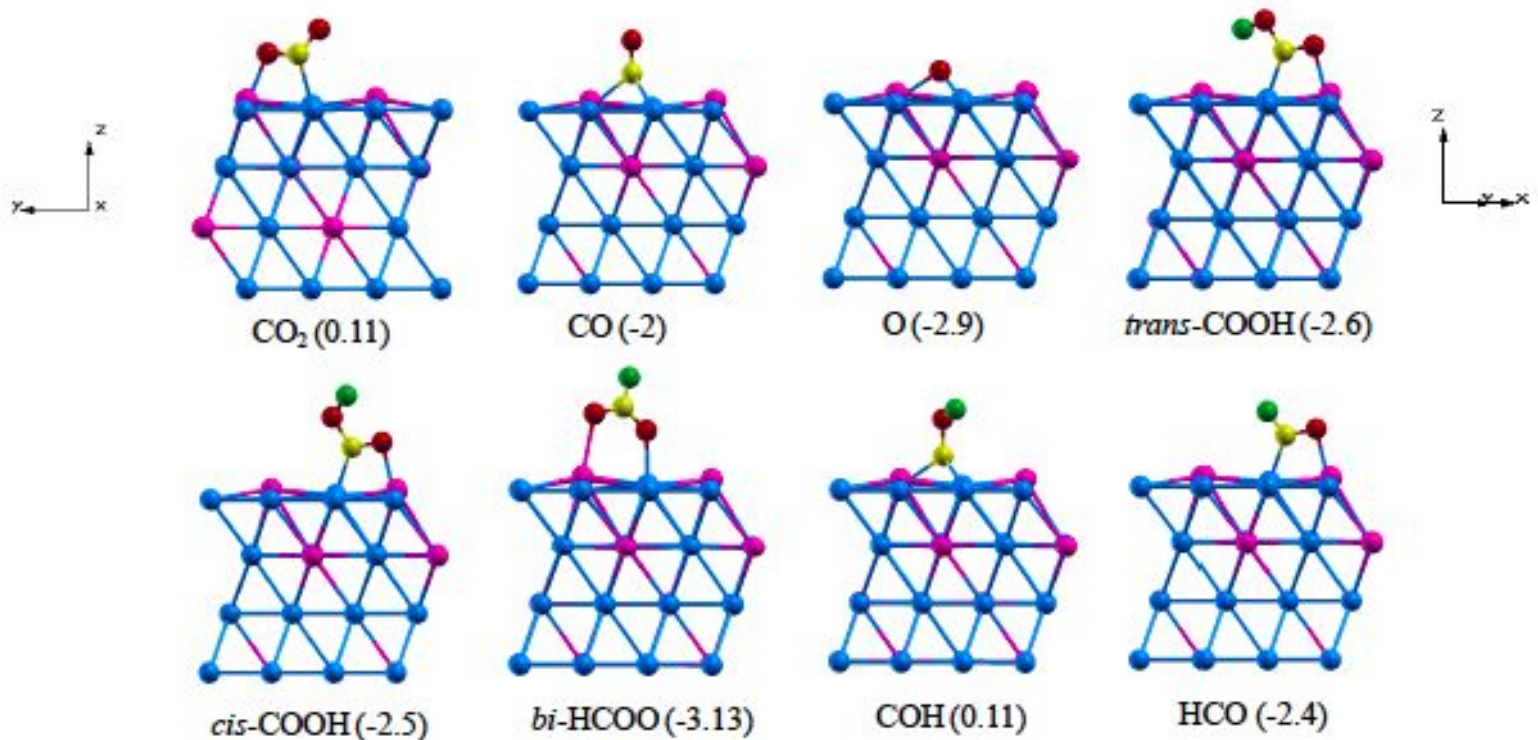

cis- $\mathrm{COOH}(-2.5)$
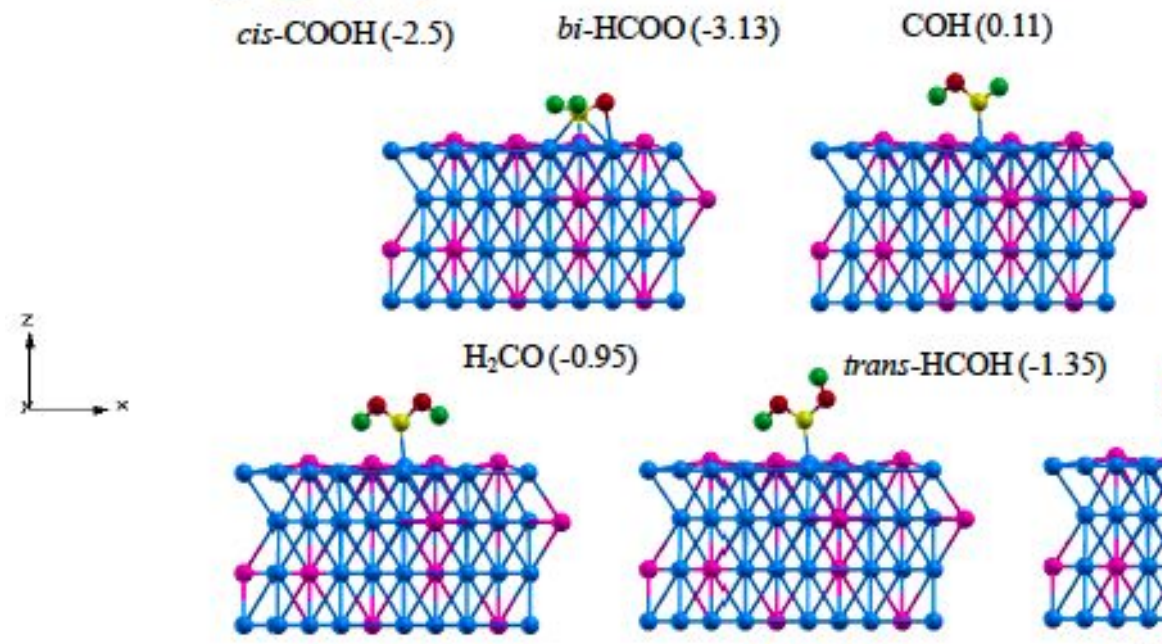

$t, t-\mathrm{COHOH}(-2.07)$
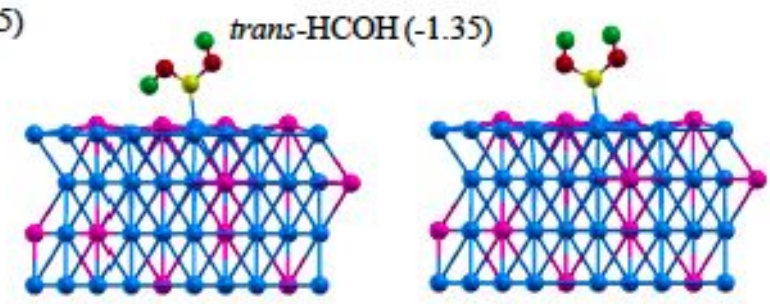

$t, c-\mathrm{COHOH}(-1.87)$

$c, c-\mathrm{COHOH}(-1.35)$
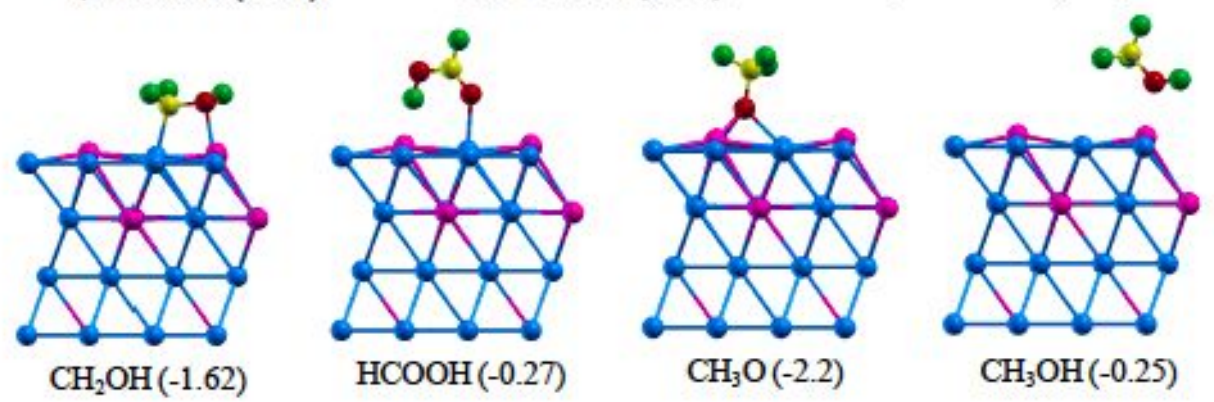

Figure S19. Optimized structures and binding energies of various intermediates occurring via various $\mathrm{CO}_{2}$ hydrogen pathways on $\mathrm{Ni}_{3}$ In (111) surface. Magenta, blue, red, green and yellow spheres correspond to $\mathrm{In}, \mathrm{Ni}, \mathrm{O}, \mathrm{H}$ and $\mathrm{C}$ atoms respectively. Binding energies are in $\mathrm{eV}$. 


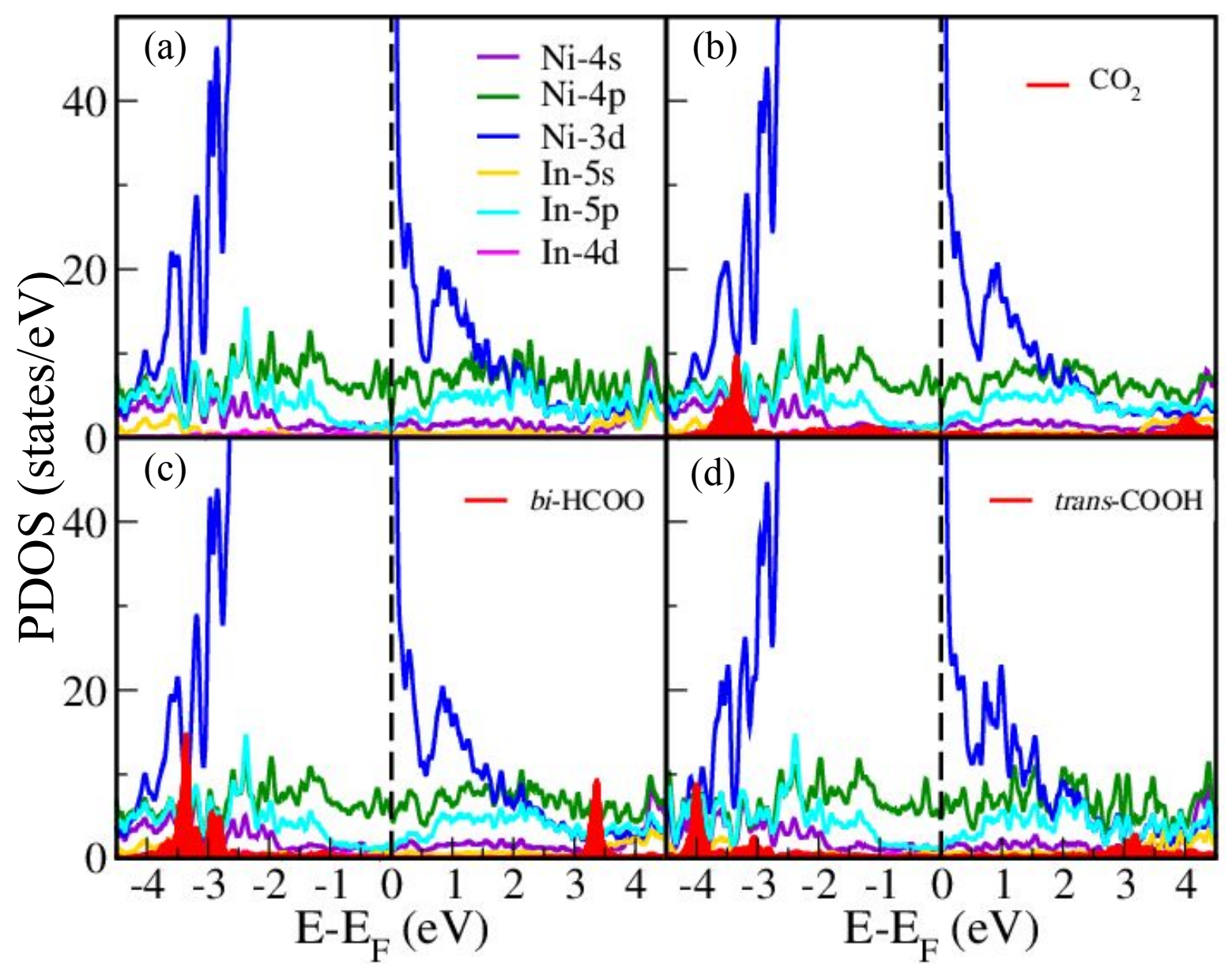

Figure S20. PDOS of (a) pristine Ni3In (111) surface and (b) $\mathrm{CO}_{2}$, (c) bi-HCOO and (d) trans-COOH adsorbed on Ni3In (111) surface. Dashed black line represents the Fermi energy. 


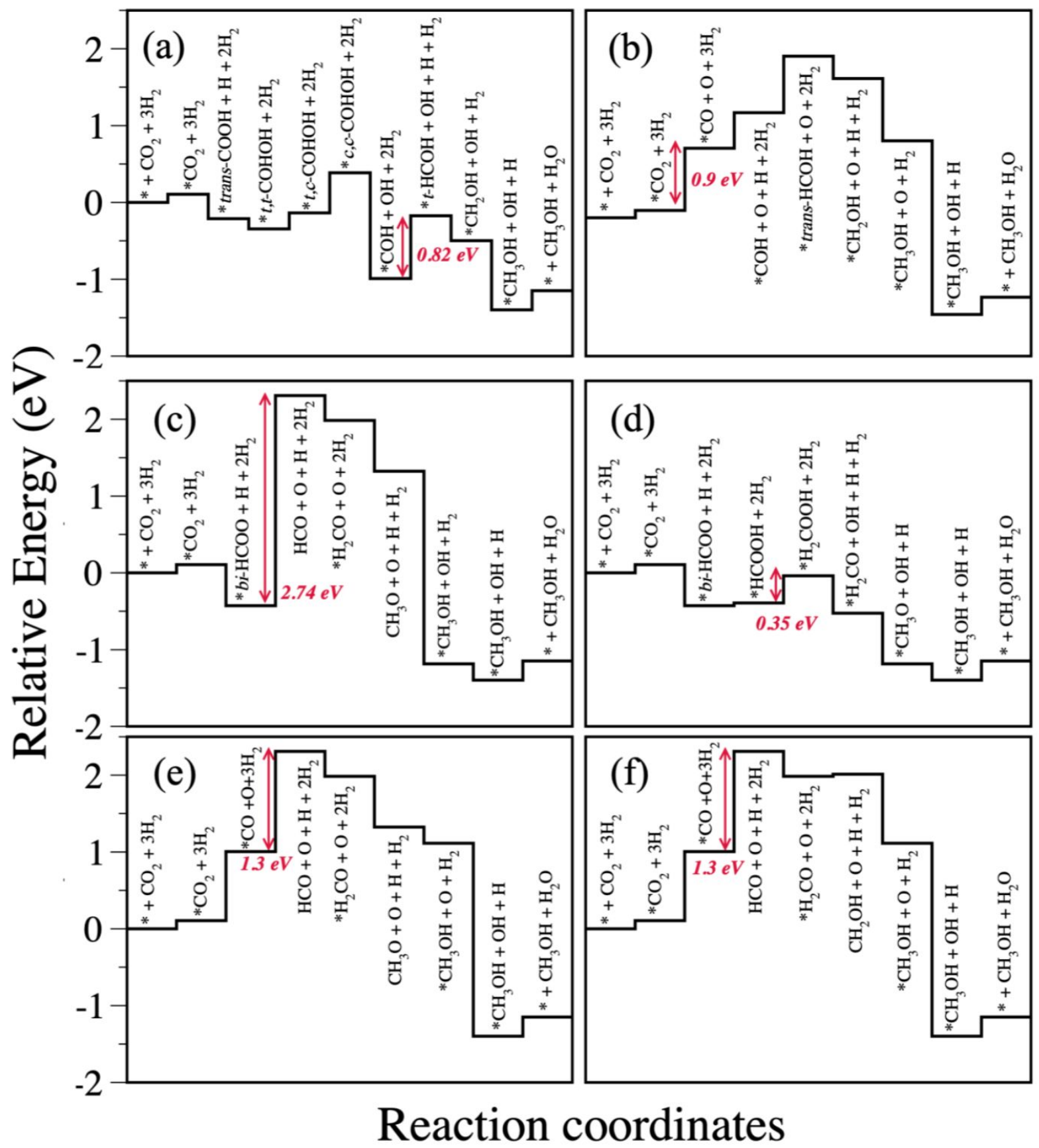

Figure S21. Relative energy diagrams of $\mathrm{CO}_{2}$ to methanol conversion on $\mathrm{Ni}_{3} \mathrm{In}$ occurring via (a) trans- $\mathrm{COOH}$, (b) CO-hydrogenation, (c) $\mathrm{HCOO}$ (2), (d) $\mathrm{HCOO}$ (3), (e) $\mathrm{CO}-$ hydrogenation (2) and (f) CO-hydrogenation (3) pathway. Red double headed arrows represent the energetically most expensive elementary step along each pathway. All values are in $\mathrm{eV}$. 


\section{References}

1. Zhao, D.; Huo, Q.; Feng, J.; Chmelka, B. F.; Stucky, G. D., Nonionic triblock and star diblock copolymer and oligomeric surfactant syntheses of highly ordered, hydrothermally stable, mesoporous silica structures. J. Am. Chem. Soc. 1998, 120 (24), 6024-6036.

2. Björk, E. M., Synthesizing and characterizing mesoporous silica SBA-15: A hands-on laboratory experiment for undergraduates using various instrumental techniques. $J$. Chem. Ed. 2017, 94 (1), 91-94.

3. Studt, F.; Sharafutdinov, I.; Abild-Pedersen, F.; Elkjær, C. F.; Hummelshøj, J. S.; Dahl, S.; Chorkendorff, I.; Nørskov, J. K., Discovery of a Ni-Ga catalyst for carbon dioxide reduction to methanol. Nat. Chem. 2014, 6, 320.

4. Bourikas, K.; Kordulis, C.; Lycourghiotis, A., The role of the liquid-solid interface in the preparation of supported catalysts. Catal. Rev. 2006, 48 (4), 363-444.

5. Grosman, A.; Ortega, C., Capillary condensation in porous materials. hysteresis and interaction mechanism without pore blocking/percolation process. Langmuir 2008, 24 (8), 3977-3986.

6. Storck, S.; Bretinger, H.; Maier, W. F., Characterization of micro- and mesoporous solids by physisorption methods and pore-size analysis. Appl. Catal. A 1998, 174 (1-2), $137-$ 146.

7. Marakatti, V. S.; Peter, S. C., Nickel-antimony nanoparticles confined in SBA-15 as highly efficient catalysts for the hydrogenation Of nitroarenes. New. J. Chem. 2016, 40 (6), 5448-5457.

8. Giannozzi, P.; Baroni, S.; Bonini, N.; Calandra, M.; Car, R.; Cavazzoni, C.; Ceresoli, D.; Chiarotti, G. L.; Cococcioni, M.; Dabo, I.; Dal Corso, A.; de Gironcoli, S.; Fabris, S.; Fratesi, G.; Gebauer, R.; Gerstmann, U.; Gougoussis, C.; Kokalj, A.; Lazzeri, M.; Martin-Samos, L.; Marzari, N.; Mauri, F.; Mazzarello, R.; Paolini, S.; Pasquarello, A.; Paulatto, L.; Sbraccia, C.; Scandolo, S.; Sclauzero, G.; Seitsonen, A. P.; Smogunov, A.; Umari, P.; Wentzcovitch, R. M., QUANTUM ESPRESSO: a modular and open-source software project for quantum simulations of materials. J. Phys.: Condensed Matter 2009, 21 (39), 395502.

9. Vanderbilt, D., Soft self-consistent pseudopotentials in a generalized eigenvalue formalism. Phys. Rev. B 1990, 41 (11), 7892-7895.

10. Perdew, J. P.; Burke, K.; Ernzerhof, M., Generalized Gradient Approximation Made Simple. Phys. Rev. Lett. 1996, 77 (18), 3865-3868.

11. Henkelman, G.; Uberuaga, B. P.; Jónsson, H., A climbing image nudged elastic band method for finding saddle points and minimum energy paths. J. Chem. Phy. 2000, 113 (22), 9901-9904.

12. Bavykina, A.; Yarulina, I.; Al Abdulghani, A. J.; Gevers, L.; Hedhili, M. N.; Miao, X.; Galilea, A. R.; Pustovarenko, A.; Dikhtiarenko, A.; Cadiau, A.; Aguilar-Tapia, A.; Hazemann, J.-L.; Kozlov, S. M.; Oud-Chikh, S.; Cavallo, L.; Gascon, J., Turning a methanation Co catalyst into an In-Co methanol producer. ACS Catal. 2019, 9 (8), 6910 6918.

13. Tan, Q.; Shi, Z.; Wu, D., $\mathrm{CO}_{2}$ hydrogenation to methanol over a highly active $\mathrm{Cu}-$ $\mathrm{Ni} / \mathrm{CeO}_{2}-$ nanotube catalyst. Ind. Eng. Chem. Res. 2018, 57 (31), 10148-10158.

14. García-Trenco, A.; Regoutz, A.; White, E. R.; Payne, D. J.; Shaffer, M. S. P.; Williams, C. K., PdIn intermetallic nanoparticles for the hydrogenation of $\mathrm{CO}_{2}$ to methanol. Appl. Catal. B 2018, 220, 9-18. 
15. García-Trenco, A.; White, E. R.; Regoutz, A.; Payne, D. J.; Shaffer, M. S. P.; Williams, C. K., $\mathrm{Pd}_{2} \mathrm{Ga}$-based colloids as highly active catalysts for the hydrogenation of $\mathrm{CO}_{2}$ to methanol. ACS Catal. 2017, 7 (2), 1186-1196.

16. Snider, J. L.; Streibel, V.; Hubert, M. A.; Choksi, T. S.; Valle, E.; Upham, D. C.; Schumann, J.; Duyar, M. S.; Gallo, A.; Abild-Pedersen, F.; Jaramillo, T. F., Revealing the synergy between oxide and alloy phases on the performance of bimetallic In-Pd catalysts for $\mathrm{CO}_{2}$ hydrogenation to methanol. ACS Catal. 2019, 9 (4), 3399-3412.

17. Shi, Z.; Tan, Q.; Tian, C.; Pan, Y.; Sun, X.; Zhang, J.; Wu, D., $\mathrm{CO}_{2}$ hydrogenation to methanol over $\mathrm{Cu}-\mathrm{In}$ intermetallic catalysts: effect of reduction temperature. J. Catal. 2019, 379, 78-89.

18. Studt, F.; Sharafutdinov, I.; Abild-Pedersen, F.; Elkjær, C. F.; Hummelshøj, J. S.; Dahl, S.; Chorkendorff, I.; Nørskov, J. K., Discovery of a Ni-Ga catalyst for carbon dioxide reduction to methanol. Nat. Chem. 2014, 6 (4), 320-324. 